\title{
RESEARCH
}

Open Access

\section{Microbial river-to-sea continuum: gradients in benthic and planktonic diversity, osmoregulation and nutrient cycling}

\author{
Hwee Sze Tee ${ }^{1}$, David Waite ${ }^{1,2}$, Gavin Lear ${ }^{1}$ and Kim Marie Handley ${ }^{1 *}$ D
}

\begin{abstract}
Background: Coastal aquatic ecosystems include chemically distinct, but highly interconnected environments. Across a freshwater-to-marine transect, aquatic communities are exposed to large variations in salinity and nutrient availability as tidal cycles create periodic fluctuations in local conditions. These factors are predicted to strongly influence the resident microbial community structure and functioning, and alter the structure of aquatic food webs and biogeochemical cycles. Nevertheless, little is known about the spatial distribution of metabolic properties across salinity gradients, and no study has simultaneously surveyed the sediment and water environments. Here, we determined patterns and drivers of benthic and planktonic prokaryotic and microeukaryotic community assembly across a river and tidal lagoon system by collecting sediments and planktonic biomass at nine shallow subtidal sites in the summer. Genomic and transcriptomic analyses, alongside a suite of complementary geochemical data, were used to determine patterns in the distribution of taxa, mechanisms of salt tolerance, and nutrient cycling.
\end{abstract}

Results: Taxonomic and metabolic profiles related to salt tolerance and nutrient cycling of the aquatic microbiome were found to decrease in similarity with increasing salinity, and distinct trends in diversity were observed between the water column and sediment. Non-saline and saline communities adopted divergent strategies for osmoregulation, with an increase in osmoregulation-related transcript expression as salinity increased in the water column due to lineage-specific adaptations to salt tolerance. Results indicated a transition from phosphate limitation in freshwater habitats to nutrient-rich conditions in the brackish zone, where distinct carbon, nitrogen and sulfur cycling processes dominated. Phosphorus acquisition-related activity was highest in the freshwater zone, along with dissimilatory nitrate reduction to ammonium in freshwater sediment. Activity associated with denitrification, sulfur metabolism and photosynthesis were instead highest in the brackish zone, where photosynthesis was dominated by distinct microeukaryotes in water (Cryptophyta) and sediment (diatoms). Despite microeukaryotes and archaea being rare relative to bacteria, results indicate that they contributed more to photosynthesis and ammonia oxidation, respectively.

Conclusions: Our study demonstrates clear freshwater-saline and sediment-water ecosystem boundaries in an interconnected coastal aquatic system and provides a framework for understanding the relative importance of salinity, planktonic-versus-benthic habitats and nutrient availability in shaping aquatic microbial metabolic processes, particularly in tidal lagoon systems.

\footnotetext{
*Correspondence: kim.handley@auckland.ac.nz

${ }^{1}$ School of Biological Sciences, University of Auckland, Auckland 1010, New Zealand

Full list of author information is available at the end of the article
}

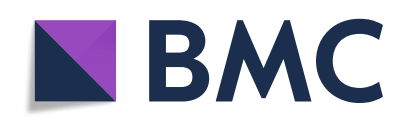

(c) The Author(s). 2021 Open Access This article is licensed under a Creative Commons Attribution 4.0 International License, which permits use, sharing, adaptation, distribution and reproduction in any medium or format, as long as you give appropriate credit to the original author(s) and the source, provide a link to the Creative Commons licence, and indicate if changes were made. The images or other third party material in this article are included in the article's Creative Commons licence, unless indicated otherwise in a credit line to the material. If material is not included in the article's Creative Commons licence and your intended use is not permitted by statutory regulation or exceeds the permitted use, you will need to obtain permission directly from the copyright holder. To view a copy of this licence, visit http://creativecommons.org/licenses/by/4.0/. The Creative Commons Public Domain Dedication waiver (http://creativecommons.org/publicdomain/zero/1.0/) applies to the data made available in this article, unless otherwise stated in a credit line to the data. 


\section{Introduction}

Across connected riverine, estuarine and marine environments, freshwater flow and tidal influx helps to redistribute nutrients and establish a strong salinity gradient [1-3]. Such gradients directly influence the resident community composition and distribution, resulting in lower benthic macrofaunal species richness within the horohalinicum (where salinities are between 5 and 8 [4]) and higher microbial richness [5-8]. Global surveys of microbial diversity have demonstrated that both salinity and environment type (such as water or sediment) are major factors influencing bacterial [9] and archaeal community composition [10]. Besides nutrients, river discharge and phytoplankton community composition are also known to drive changes in planktonic estuarine communities [11, 12]. Previous studies of planktonic prokaryotic communities across freshwater-to-marine transects have highlighted significant differences in gene abundances related to glycolysis, respiration, catabolic pathways, osmolyte and metal transport, and the biosynthesis of quinones and isoprenoids between low and high salinities, in line with the shifts in taxonomic groups [13, 14]. However, little is known about the collective microbial ecology of bacteria, archaea and microeukaryotes in sediment and water across river-to-sea salinity gradients; how these factors (water, sediment, salinity) affect microbial gene expression across this environmental continuum also remains largely unexplored.

A key factor shaping microbial community distributions across salinity gradients is lineage-specific adaptations for salt tolerance $[6,8-10,12,15,16]$. Bacteria adopt two distinct strategies to cope with osmolarity changes in their environment: (1) a salt-in strategy which promotes $\mathrm{K}^{+}$accumulation and (2) the synthesis or uptake of organic compatible solutes which function as osmoprotectants [17]. Various $\mathrm{K}^{+}$uptake systems have been reported to date, for example, both $\operatorname{trk} A$ and kup systems in hyperosmotic environments, and the $k d p$ system for low external $\mathrm{K}^{+}$concentrations [18-21]. Bacteria can also employ various $\mathrm{Na}^{+} / \mathrm{H}^{+}$antiporters and $\mathrm{Na}^{+}$translocating dehydrogenases to export $\mathrm{Na}^{+}$extracellularly in highly saline environments $[13,15]$. Taxa and strategies employed are therefore predicted to change across coastal salinity gradients. Although, certain lineages, for instance, members of the order Pelagibacterales (SAR11), have been found at different salinities, suggesting ecological adaptations within microbial lineages to salt $[16,22]$.

In addition to salinity, dramatic differences in nutrient availability and types are typically observed across freshwater to marine systems and have been predicted to strongly influence community composition and function [1-3]. These systems mix nitrogen-rich freshwater with sulfate and phosphate-rich marine water [23, 24].
Sulfate-rich saline water promotes the formation of ferrosulfides, resulting in less phosphate sorption in sediments and higher phosphate concentrations in saline water [23, 25, 26]. Riverine systems, however, are often phosphate-limited due to greater phosphate sorption in non-saline sediments [27]; it is therefore likely that freshwater microbial communities rely on high-affinity phosphate uptake mechanisms. Estuarine conditions are comparatively rich in both nitrogen and phosphorus, which support the growth of primary producers [28], and in turn, heterotrophs $[29,30]$. Benthic photosynthesis has been shown to promote nutrient-regulating biogeochemical processes in estuaries, such as coupled nitrification-denitrification [31]. However, the relative contribution of each of the taxa within the microbiome toward biogeochemical cycling across river-estuarymarine transects remains understudied.

To determine microbial taxonomic and functional diversity, and metabolic hotspots, across a river-to-sea transect, we sampled benthic sediment (hereafter referred to as "benthic" samples) and overlying water ("planktonic" samples) along a 5-km stretch connecting the Waiwera river, estuary and beach (Auckland, New Zealand). The Waiwera river predominantly drains rural pastoral catchments [32], and is therefore impacted by anthropogenic activities, as is typical for estuaries globally $[33,34]$. The river and estuary have a water depth of approximately $0.2-1 \mathrm{~m}$, and the estuary is classified as a permanently open tidal lagoon estuary [35] and is subjected to daily tidal influxes from the Hauraki Gulf (Pacific Ocean). Tidal lagoon systems, also known as bar-built coastal lagoons, or barrier enclosed lagoons, can be found throughout the world (e.g. Laguna Madre in Texas, USA [36]; Mosquito Lagoon in Florida, USA [37]; and Paravur estuary in Kerala, India [38]) and occupy about $13 \%$ of the global coastline [39]. They are also the most common estuary systems in New Zealand [40] and the UK [41]. A natural continuous salinity gradient occurs along the Waiwera river and estuary, potentially exerting a strong influence on the assembly of microbial communities. We hypothesised that non-saline, saline, water and sediment communities would be strongly demarcated by distinct prokaryotic and eukaryotic compositions, and utilise distinct osmoregulatory and nutrient acquisition mechanisms, reflecting, for example, nutrient limitations in the freshwater $(\mathrm{P})$ and marine $(\mathrm{N})$ endmember environments. Combining metagenomic, metatranscriptomic and geochemical data, we identified the impact of salinity and nutrient availability on prokaryotic and microeukaryotic community diversity and on critical physiological and ecological processes, such as osmoregulation, primary production and nutrient cycling. 


\section{Results and discussion}

\section{Community partitioning based on salinity and sediment-} water habitat preferences

Contribution of salinity versus other environmental parameters in shaping microbial communities

Nutrient and salinity gradients are major features of estuarine systems, leading to higher estuarine productivity [1-3]. Accordingly, we observed a general decrease in nitrate concentrations along the Waiwera river-estuarysea transect, higher organic carbon concentrations in brackish sediments, and an increase in dissolved reactive phosphorus and sulfate with salinity (Fig. 1a, b). We therefore tested the contribution of salinity relative to other geochemical variables in differentiating prokaryotic and microeukaryotic composition along this transect. To achieve this, near full-length small subunit (SSU) rRNA gene sequences were assembled and clustered into 6964 bacterial, 291 microeukaryal and 79 archaeal operational taxonomic units (OTUs, unique at 97\% sequence identity). Results showed salinity best explains differences in sediment bacterial and microeukaryal community composition (Spearman's correlation coefficient $\rho=0.43-$ 0.91 ) and planktonic bacterial and microeukaryal composition ( $\rho=0.78-0.91$, Supplementary Table 1$)$. Two subsets of parameters were maximally correlated with dissimilarities among planktonic (salinity, ammonium, and phosphate, $\rho=0.19$ ) and benthic archaea (salinity and nitrate, $\rho=0.90$, Supplementary Table 1), suggesting that besides salinity, nutrients play important roles in structuring these aquatic communities, in agreement with previous studies [11, 12, 22]. Overall, our results correlate strongly with research showing salinity is a major global driver of prokaryotic community composition $[9,10]$.

Although salinity strongly differentiated each of the planktonic and benthic communities relative to other geochemical factors, water-vs-sediment environment type was found to be the single most important factor distinguishing microbial communities overall (Fig. 1c). This was due to consistently large differences in benthic and planktonic communities across the gradient, regardless of salinity (Fig. 1d; Supplementary Table 2), which resulted in significantly different benthic and planktonic microbial communities overall based on Bray-Curtis dissimilarities (Benjamini-Hochberg adjusted $p<0.05$, Supplementary Table 3; Fig. 1d and Supplementary Figure 1). Results, therefore, support research highlighting the importance of these environment types, along with salinity, in structuring microbial communities $[9,10]$. However, few studies, as here, have compared sediment and water communities directly within the same system $[42,43]$. We found that only when comparing the effect of end-member salinities (non-saline vs marine) on benthic and planktonic communities were differences in microbial community composition comparable to those between water and sediment at the same salinity (BrayCurtis dissimilarities 0.97 to 0.99 on average; Supplementary Table 2). Predictably, the combination of salinity and environment type contributed to almost entirely distinct communities (Bray-Curtis dissimilarities of 0.99 to 1.0 , or 1.0 on average). Sediment and water environments are typically separated by large differences in redox processes, oxygen, nutrient and terminal electron acceptor availability $[44,45]$. This is also evident in our study, where concentrations of ammonium, nitrate and dissolved non-purgeable organic carbon (DNPOC) were significantly higher in the sediment porewater, compared with the overlying water column (Wilcoxon, $p<0.05$, Fig. 1b).

\section{Salinity gradients and the non-saline-saline divide in sediment and water microbial communities}

Consistent with salt as a major driver of aquatic community composition, reconstructed SSU rRNA and Braken2-estimated species abundance profiles indicated large differences in the composition of bacteria, archaea and microeukaryotes across the salinity gradient within sediment and water environments, although bacteria invariably dominated both the benthic and planktonic communities (Fig. 2a, trends exhibited by key taxa are described in Supplementary Information). An overall decrease in both planktonic and benthic community similarities occurred with increased difference in salinity and geographic distance (Fig. 1e and Supplementary Figure $2 \mathrm{a})$, resulting in a clear separation between non-saline and saline community compositions (Fig. 1d). Results reflect the substantial physiological adaptations required for salt tolerance [14-16]. The rate of increasing dissimilarity was far greater among water column communities (analysis of covariance, $p<0.0001$ ), owing to the relatively high similarity between neighbouring communities. Greater spatial dissimilarity overall was observed among communities at benthic sites, including among sites located only $5 \mathrm{~m}$ apart (Fig. 1e). This suggests sediment is a more heterogeneous environment compared to the overlying water, and is consistent with previous comparisons of planktonic and benthic microbial communities in river or coastal settings $[42,43]$. The strong spatial heterogeneity of benthic communities is likely due to greater stability within sediments, which are less impacted by tidal mixing $[1,46]$.

To further compare community differences across the transect, we categorised sediment and overlying water samples as each belonging to three distinct environments (non-saline, 0-0.5; brackish, 0.5-30; marine, 30$35)$, based on the salinity of porewater or water samples, respectively (Fig. 1a and Supplementary Table 4) [47]. The benthic community composition (based on OTU 


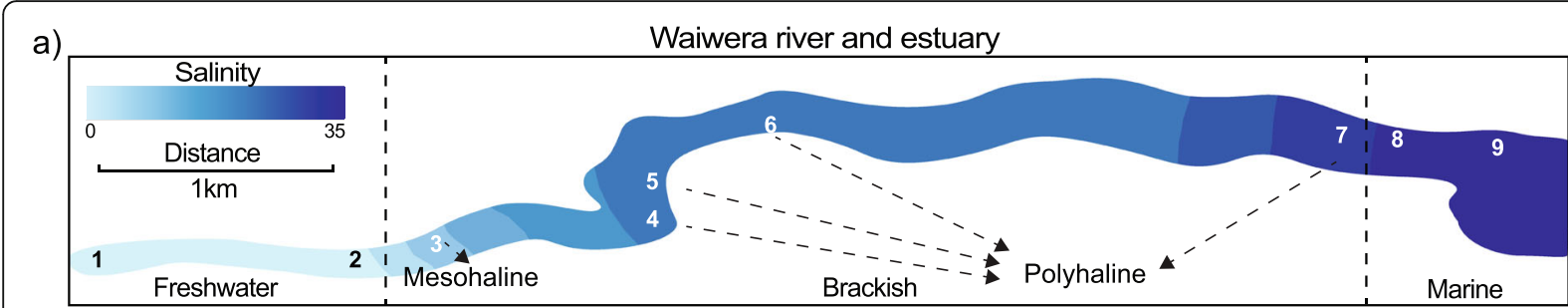

b)

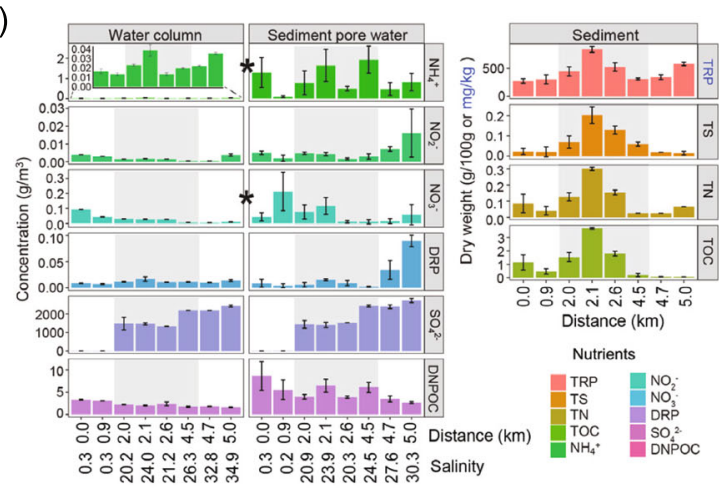

d)

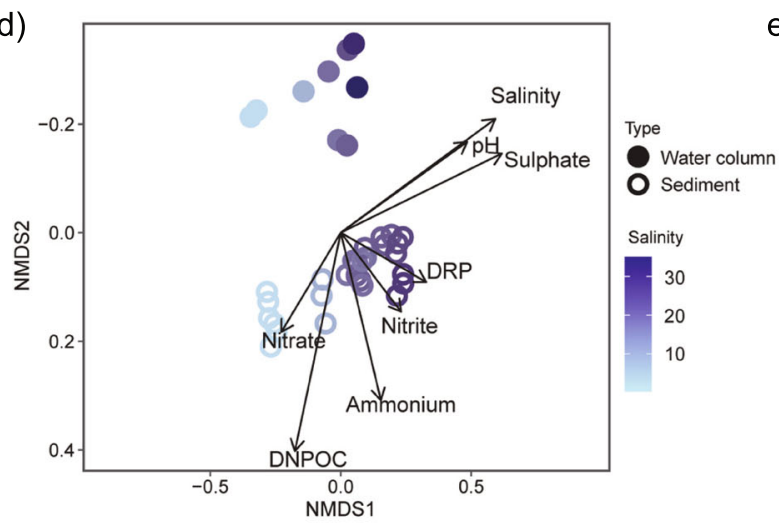

c)

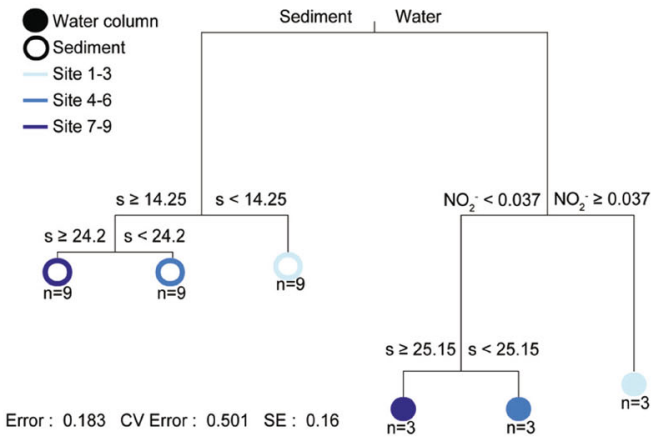

e)

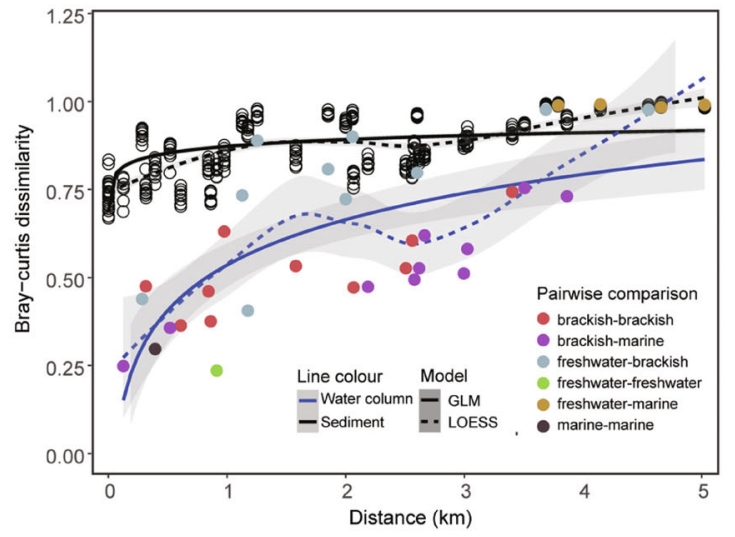

Fig. 1 Plots showing variation in nutrient concentrations and community composition. a The Waiwera river sampling locations (1 to 9) with water column salinity gradient (0-35) shown using kriging interpolation. b Nutrient concentrations in sediment, sediment pore water and water samples taken in triplicate across the sampling sites. Grey background represents brackish sites (2.0-4.5 km along the transect). Abbreviations: TRP total recoverable phosphorus, TS total sulfur, TN total nitrogen, TOC total organic carbon, DRP dissolved reactive phosphorus, DNPOC dissolved non-purgeable organic carbon. Error bars represent standard errors of means. Asterisks (*) indicate a significant difference between all water column and sediment samples (Wilcoxon $p<0.05$ ). c Multivariate regression tree of microbial community abundance data associated with the environmental variables. Abbreviations: $s$ salinity, $\mathrm{NO}_{2}{ }^{-}$nitrite, $n$ sample size. Units: nitrite $(\mathrm{g} / \mathrm{m} 3)$. $\mathbf{d}$ NMDS ordination of small subunit rRNA gene sequences based on Bray-Curtis dissimilarities. Samples are coloured according to salinity. Environmental vectors were fitted onto the NMDS scores of the microbial community by the R-function envfit $(p<0.05$, permutation $=999)$. e Distance-decay relationships of community dissimilarity (Bray-Curtis index) with increasing geographical distance. The regression lines were fitted to the data points using log generalised linear (GLM, solid line) and LOESS (dotted line) models. Each data point represents a pairwise comparison of samples from the water column (closed circles) or sediment (open circles)

abundances) was significantly different among nonsaline, brackish and marine environments (BenjaminiHochberg adjusted $p<0.05$, Supplementary Table 3). Fewer benthic and planktonic OTUs were shared between freshwater and brackish (6.4-10.9\%) than between saline brackish and marine (13.5-17.9\%) environments (Supplementary Figure 2b). This is reflected by the planktonic distance-decay curve, which shows greater dissimilarity at the freshwater- brackish transition (peak at $\sim 1.5 \mathrm{~km}$ ) and higher similarity at the brackish-marine transition (trough at $\sim 2.5 \mathrm{~km}$; Fig. 1e). These results support findings that salinity strongly partitions freshwater and marine planktonic prokaryotic communities [14, 22], and also demonstrate that the relatively small increase in salinity (of 8) spanning the freshwater-saltwater transition represents a powerful ecological barrier for both benthic and planktonic communities. 


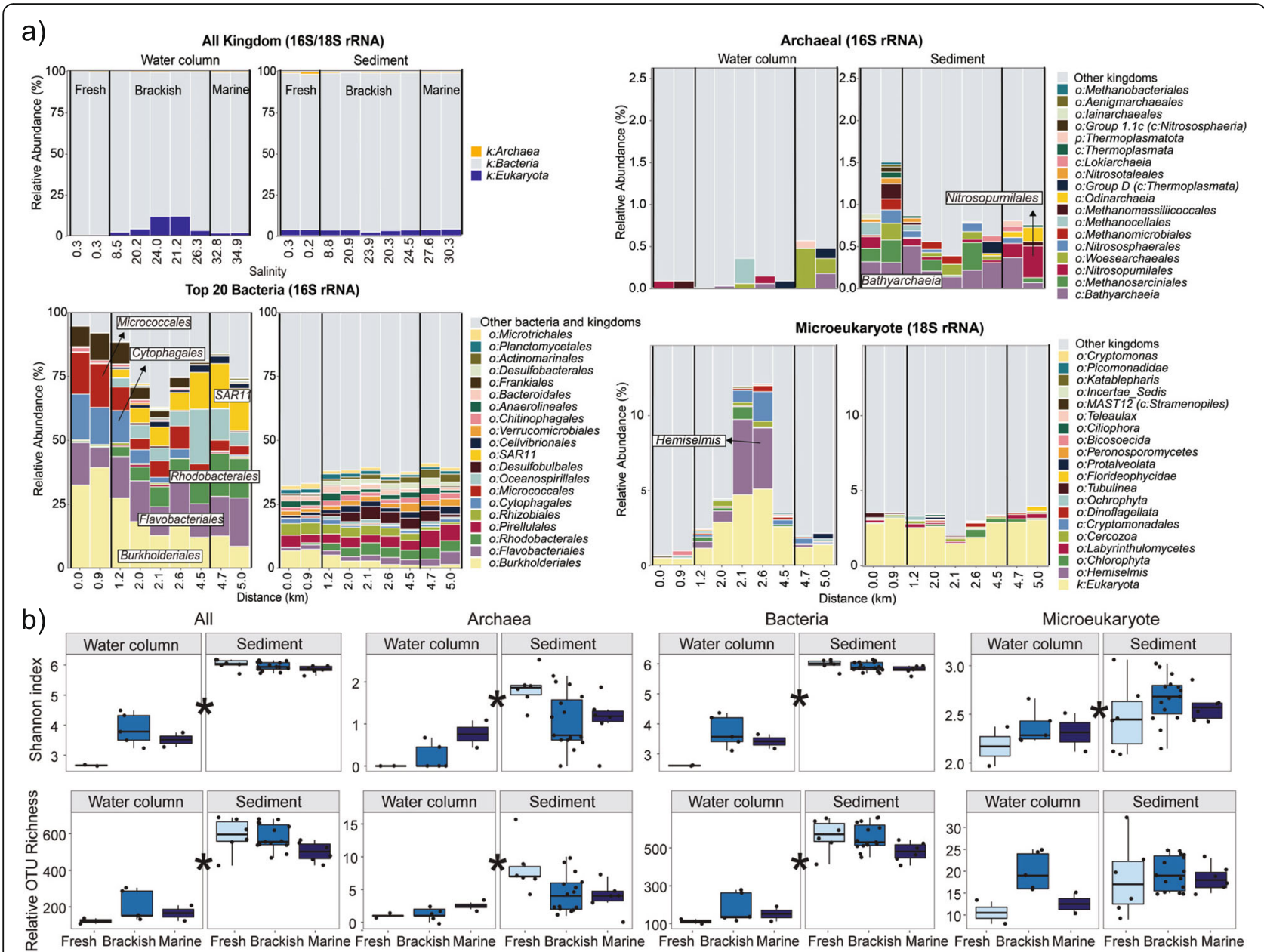

Fig. 2 Community distribution and alpha diversity. a Bar plots indicate relative abundances of EMIRGE-reconstructed 16S and 18S rRNA gene sequences. Site salinities are shown in the upper left plots, and transect distances are given in the lower plots. Taxa are coloured at the order level. For each plot, samples from the water column (left) and sediment (right) are further categorised into freshwater, brackish or marine, as indicated in the top left plot. b Boxplots illustrate Shannon indices and relative OTU richness in both sediment and water column environments across the salinity gradient for archaeal, bacterial and microeukaryal communities $(n=36)$. Colours indicate environment type (freshwater, brackish and marine) based on the salinity gradient. Boxes represent the interquartile range (IQR) between the first and third quartiles and the horizontal line inside the box represents the median. Whiskers represent the lowest and highest values within 1.5 times the IQR from the first and third quartiles, respectively. Individual sample values are shown as dots. Asterisks $\left(^{*}\right)$ indicate a significant difference between all water column and sediment samples (Wilcoxon $p<0.05$ )

\section{Influence of salinity on microbial alpha diversity}

Microbial community alpha diversity, measured via the Shannon index and relative OTU richness, was significantly higher in sediments across the entire transect (Fig. 2a; Wilcoxon, $p<0.001$ ), likely due to greater nutrient availability (Fig. 1b), availability of terminal electron acceptors, greater diversity in environmental niche space and greater community stability associated with more static environmental conditions $[1,46,48]$. Benthic and planktonic communities exhibited opposing trends in richness and Shannon diversity across the salinity gradient (Fig. 2b). In contrast to previous planktonic studies that showed no clear trend in diversity $[6,7]$ or a reduction in diversity with increasing salinity $[11,12]$, the median taxon richness increased from a minimum in freshwater to a maximum in marine water (123 to 166 OTUs), while the Shannon index increased from 2.7 in freshwater to 3.5-3.8 in brackish and marine water. Sediment community Shannon diversity and richness decreased along this gradient (Shannon indices from 6.0 to 5.9; OTUs from 596 to 502). While greater diversity or taxon richness in marine water versus freshwater may be attributed to OTUs being flushed out to sea, we observed no evidence for this, as very few OTUs $(<3 \%)$ were shared between these systems (Supplementary Figures $2 \mathrm{~b}$ and 3 ). The same patterns were observed when considering specific lineages (archaea, bacteria and microeukaryotes), except benthic microeukaryotes 
displayed no clear trend (Fig. 2b). Results showed no obvious reduction in prokaryotic or microeukaryote richness in the brackish zone, in contrast with Remane's species minimum concept, which proposes minimum richness for benthic macrofauna in the brackish horohalinicum [4]. Our results on prokaryotes and microeukaryotes, taken together with other studies that have found a protistan species-maximum in brackish water [5, 49], suggest essential differences in taxa diversity associated with salinity gradients.

\section{Osmoregulation, nutrient metabolism and primary production across environments Differences in functional gene abundance and expression across sampled gradients and relationship to taxa composition}

Overall, metabolic profiles (genes and genes expressed) decreased in similarity with increasing salinity divergence (Supplementary Figure 2c). However, neither taxonomic nor functional gene data were strong indicators of gene expression, as previously observed for freshwater-to-marine planktonic [14], ocean [50] and hypersaline desert environments [51]. Mantel tests showed that while taxonomic beta-diversity was strongly correlated with differences in functional potential $(\rho=0.90, p$ $<0.01$ ), it was only weakly correlated with differences in gene expression $(\rho=0.54, p<0.01)$. Similarly, we identified a moderate correlation between differences in gene and transcript abundances $(\rho=0.70, p<0.01)$. Microbial composition is thought to be a poor predictor of ecological processes due to functional redundancy and variations in environmental response, leading to marked differences in transcript expression [50-53]. To ascertain which metabolic features, associated with osmoregulation, nutrient metabolism and primary production, were strongly differentiated among freshwater, brackish and marine environments, and between water and sediment, we applied linear discriminant analysis effect size (LEfSe) and weighted gene co-expression network analysis (WGCNA). LEfSe results revealed 25 discriminative features from the metagenomes and 42 from the metatranscriptomes (Fig. 3a; Kruskal-Wallis $p<0.05$, Supplementary Table 5), indicating a large shift in metabolic potential and, most notably, activity across this transect (Supplementary Figure 4). In agreement with LEfSe results, WGCNA analysis showed 4 out of 6 coexpressed gene clusters were significantly associated with environment (Supplementary Figure 5; details are described in Supplementary Information), revealing a clear division in metabolism related to nutrient acquisition and osmoregulation between sediment and water and between saline and non-saline environments. Genes and transcript abundances related to phosphorus metabolism, photosynthesis and osmoregulation were
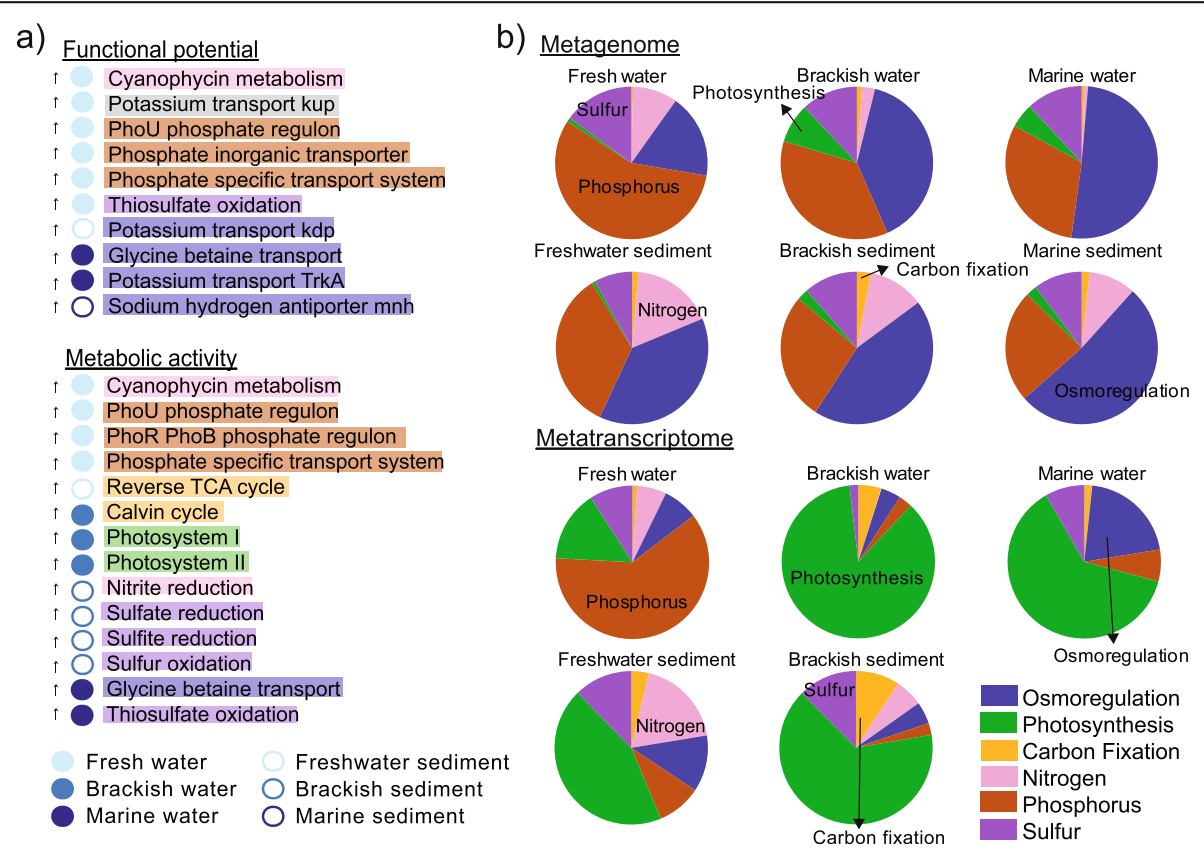

Fig. 3 Discriminative features and distribution of functional potential and metabolic activity across the salinity gradient. a Differentially abundant metabolic functions from metagenomic (top, $n=36$ ) and metatranscriptomic (bottom, $n=33$ ) data, as determined by LEfSe (specific pathways from Supplementary Table 5). Arrows indicate functions were significantly over-represented in their specific habitat. b Pie charts showing the relative fraction of functional gene categories across the freshwater-to-marine gradient based on metagenome and metatranscriptome data. Transcriptomic data were not obtained for marine sands due to low RNA quality. Colours in both panels indicate key nutrient acquisition and osmoregulation pathways 
significantly higher in fresh, brackish and marine water, respectively (Fig. 3 and Supplementary Figure 5). In contrast, brackish sediment was characterised by significantly higher sulfur metabolism (Fig. $3 a$ and Supplementary Figure 5). Nutrients in tidal lagoon or bar-built estuaries, such as in this study, are generally derived from runoff from land or groundwater inputs, and promote primary productivity and nutrient regeneration in brackish systems [54]. Fewer genes and transcripts were identified as significantly and differentially abundant among benthic environments due to large variations in their relative abundance, reflecting the high spatial heterogeneity in benthic community composition and nutrient availability (Figs. 1b and 2a).

\section{Distinct non-saline and saline osmoregulation strategies}

In line with previous research indicating that microbial taxonomic distributions are primarily driven by salinity [14], largely due to lineage-specific adaptations to salt tolerance $[15,17,55]$, our results show that dominant microbial taxa in non-saline (Betaproteobacteria) and saline (Alphaproteobacteria and Gammaproteobacteria) habitats adopted distinct osmoregulation strategies (Figs. 4 and 5 and Supplementary Figure 6 ). While $\mathrm{K}^{+}$acquisition and $\mathrm{Na}^{+}$export are considered important mechanisms for osmoregulation in brackish or marine environments [14, 15], results here illustrate that $\mathrm{K}^{+}$ transport is also crucial in freshwater communities. We observed a significantly greater abundance of the potassium $\left(\mathrm{K}^{+}\right)$transporter gene $k d p$, in non-saline sediment (Kruskal-Wallis, $p<0.05$, Fig. 4 and Supplementary Figure 4). In contrast, trkA was more abundant in marine water and sediment (Fig. 4). The trkA system is prominent under hyperosmotic stress [19], characteristic of the marine environment. The repressible high-affinity $\mathrm{K}^{+}$ transporter, $k d p$, is known to be active at low external $\mathrm{K}^{+}$concentrations [21], consistent with freshwater environments.

We found a significantly higher abundance of $\mathrm{Na}^{+} / \mathrm{H}^{+}$ antiporter genes (mnhABCDEFG) in marine sediment, and higher expression of $\mathrm{Na}^{+}$translocating dehydrogenase $(n q r F)$ and glycine betaine transporter (bcct and pro $X V$ ) genes in marine water (Figs. $3 \mathrm{a}$ and 4, Supplementary Figure 4), primarily contributed by Alphaproteobacteria and Gammaproteobacteria, with an apparent increase in gene expression starting from site 7 (salinity = 26; Supplementary Figure 6). Glycine betaine transporter and $\mathrm{Na}^{+} / \mathrm{H}^{+}$antiporter gene expression in the water was also significantly correlated with salinity $(\rho=$ $0.90-0.95, p<0.01$, Supplementary Figure 6). In the marine environment, some bacteria rely on $\mathrm{Na}^{+}$-motive force to routinely export $\mathrm{Na}^{+}$via various $\mathrm{Na}^{+} / \mathrm{H}^{+}$antiporters and $\mathrm{Na}^{+}$translocating dehydrogenases [56-59]. Increased abundance and expression of $\mathrm{Na}^{+}$transporter genes with salinity suggests that brackish and marine microorganisms increasingly exported destabilising $\mathrm{Na}^{+}$ in exchange for greater accumulation of $\mathrm{K}^{+}$within cells, which stabilise acidic salt-adapted proteins [17, 60, 61]. Glycine betaine transporters, in contrast, uptake organic solutes to achieve osmotic equilibrium [17, 62], or for metabolism and ATP generation [63].

\section{Spatial distribution of light and dark primary production}

Autotrophic microbial and microeukaryotic communities play crucial roles in aquatic primary production and form the base of the aquatic food chain. We observed taxonomically diverse organisms across the river-marine transect with capabilities for oxygenic or anoxygenic photosynthesis and carbon fixation via the Calvin-Benson, Wood-Ljungdahl and reverse tricarboxylic acid (TCA) pathways (Figs. 5 and 6). Gene expression related to primary production was the highest in water in the mid-brackish zone (salinity $=24$; Figs. 4 and 6 ). This corresponded with increased phytoplankton relative abundance, particularly Cryptophyta (genus Hemiselmis; Figs. 2a and 6), and a peak in ammonium $\left(0.04 \mathrm{~g} / \mathrm{m}^{3}\right.$, Fig. 1b) - the preferred nitrogen source for Cryptomonads [64] (Supplementary Information). Data indicate phytoplankton actively assimilated carbon via the Calvin-Benson cycle (RuBisCO) and conserved energy via oxygenic photosynthesis (photosystems I and II; Figs. 5 and 6). In contrast, diatoms can photosynthesise and fix carbon efficiently under low light [65]. Coastal lagoon systems, including the Waiwera river, are shallow water bodies $(<5-\mathrm{m}$ depth) [66], where light can penetrate to the bottom sediments and promote benthic primary productivity [54]. Consistent with this, Waiwera had a low median river turbidity of 7.0 Nephelometric Turbidity Units (NTU) reported for the sampling year (2018, https://www.lawa.org.nz/), and results show that diatoms dominated sediment primary production across the brackish transect (Fig. 6). Increased phytoplankton primary production, and consequently, sinking biomass, may explain the higher concentrations of total sedimentary organic carbon, nitrogen and phosphorus measured at the mid-brackish site (Fig. 1b). High benthic primary production (Figs. 3b and 6) and mud content may also contribute to higher organic carbon in brackish sediment [67-70] (average 17.8\% versus 4.3\% elsewhere, Supplementary Table 4).

There is limited information on carbon fixation pathways utilised across salinity gradients, but a few studies show that estuaries are global hotspots for carbon cycling and assimilation [28, 71, 72]. Here, the Calvin cycle, in conjunction with photosynthesis, was significantly more highly expressed in brackish water (significant, LDA score $\geq 2$ ), whereas genes related to dark carbon fixation, such as the reductive TCA cycle and Wood- 


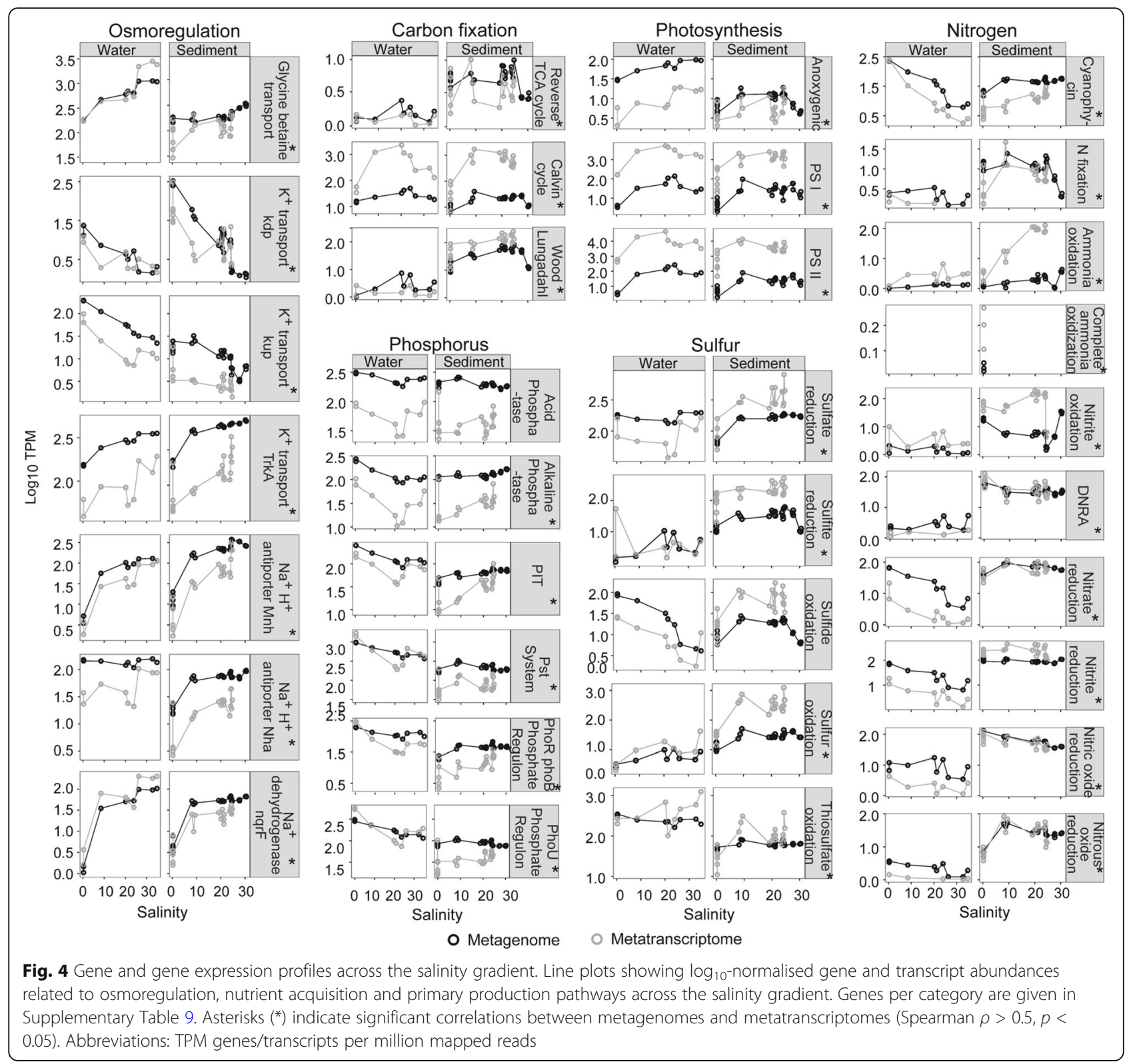

Ljungdahl pathway, were primarily expressed in sediment environments. While we did not measure dissolved oxygen in this study, microorganisms undertaking dark carbon fixation typically thrive across a redox gradient, such as the oxic-anoxic interface in aquatic sediments $[73,74]$. Both the Wood-Ljungdahl pathway and reductive TCA cycle are strongly associated with anaerobes, although the latter is also found in microaerobes and some aerobes $[75,76]$. Among organisms undertaking dark carbon fixation, we found that the reverse TCA cycle genes (aclA) were significantly more highly expressed in non-saline sediment (LDA score $\geq 2$ ), and predominantly by Nitrospira (Fig. 6), which our results indicate also undertook complete ammonia oxidation (comammox) in this environment (Fig. 5). In contrast,
Wood-Ljungdahl pathway codh genes were highly expressed in brackish sediments, primarily by Chloroflexi and Deltaproteobacteria (Figs. 5 and 6). Wood-Ljungdahl pathway gene expression in the brackish sites was at least 100 times greater than reverse TCA cycle gene expression, but 10 times less than the Calvin cycle gene expression (Figs. 5 and 6), highlighting the significance of the Calvin cycle and Wood-Ljungdahl pathway for carbon assimilation in this brackish system.

\section{Nitrogen and phosphorus acquisition in freshwater and brackish environments}

Ammonium was the main inorganic nitrogen source observed in benthic environments $\left(0.1-2.7 \mathrm{~g} / \mathrm{m}^{3}\right)$, but was relatively scarce in the water column $\left(<0.04 \mathrm{~g} / \mathrm{m}^{3}\right)$, 


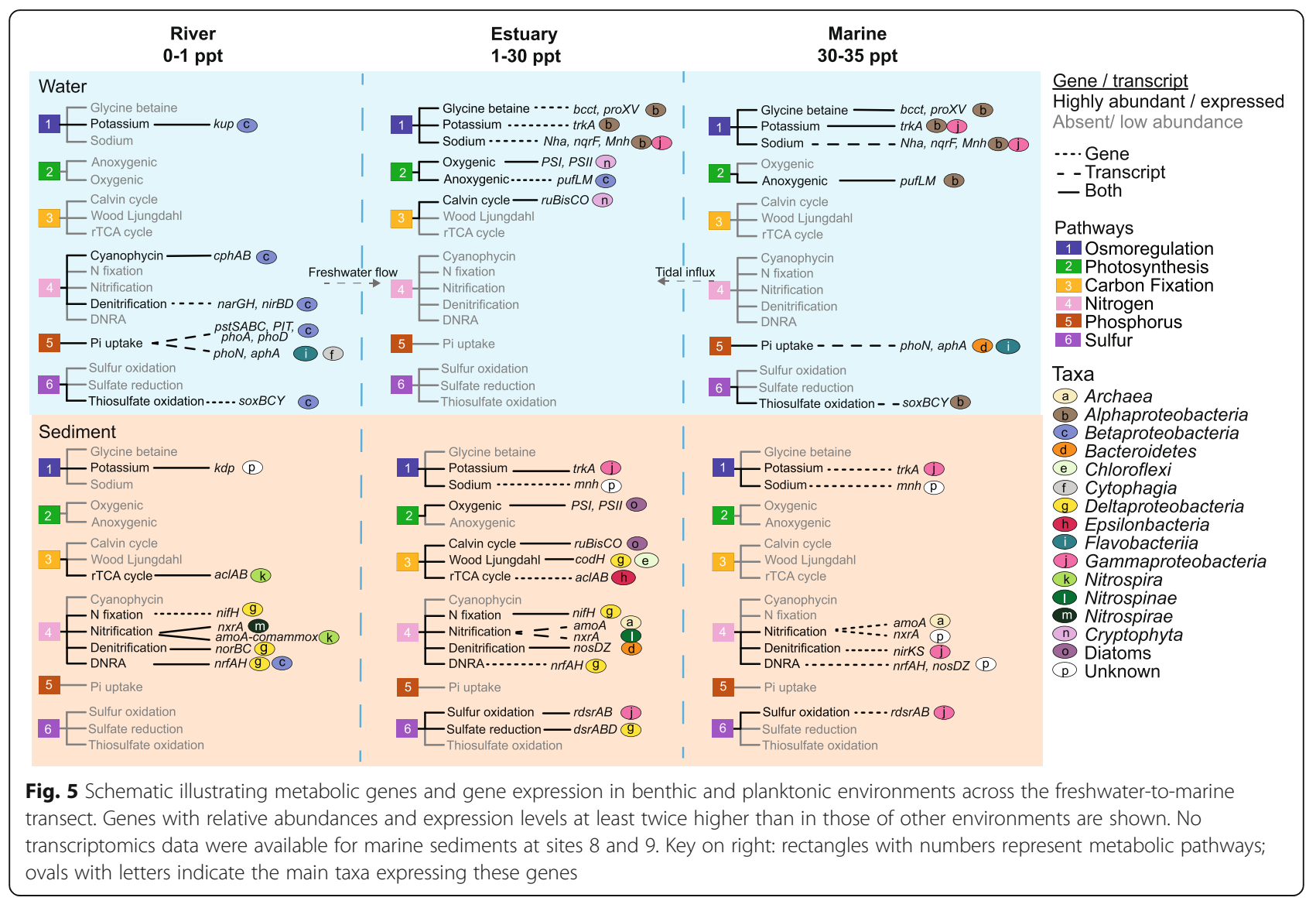

where nitrate and nitrite concentrations were also lower (Fig. 1b and Supplementary Table 4). While ammonium, derived from anthropogenic activities, can be the dominant form of $\mathrm{N}$ entering shallow tidal lagoon settings [54], such riverine inputs can also be nitrate-dominated [77], as observed in this study (Fig. 1b). This suggests considerable benthic regeneration of ammonium [54] in the sampled sediment (top $2 \mathrm{~cm}$ ). Higher ammonium concentrations in the benthic zones may also be due to sedimentation of phytoplankton blooms, boosting both nitrate uptake and ammonium release in benthic environments $[78,79]$. Nitrate is therefore depleted during spring bloom progression [54]. To deal with fluctuating nitrogen availability in aquatic ecosystems, microbial communities are equipped with strategies for nitrogen assimilation (e.g. fixation) and storage (cyanophycin) [80, 81]. Genes related to nitrogen fixation (nifABDH) were detected and expressed in non-saline and brackish sediment (Figs. 4 and 5; no transcriptomic data are available for marine sediment), although ammonium levels were around $1 \mathrm{~g} / \mathrm{m}^{3}$ in some of these sites (Fig. $1 \mathrm{~b}$ and Supplementary Table 4). Excess ammonium $\left(>50 \mathrm{~g} / \mathrm{m}^{3}\right)$ or oxygen $(>2 \%)$ is reported to inhibit nitrogenase activity [82-84]. However, as ammonium concentrations tested were orders of magnitude higher than those we detected, ammonium concentrations in the present study may not have affected nitrogenase activity. In contrast, there were few to no nifABDH transcripts detected in the overlying water, likely due to low predicted iron and molybdenum concentrations [85], which is characteristic of marine water [81]. High iron and molybdenum are required for the FeMo nitrogenase cofactor in all known diazotrophs [86]. In some bacteria, excess nitrogen assimilated is stored intracellularly as cyanophycin granules comprised of nitrogen and carbon storage polymers [80, 87]. Our results indicate that genes related to cyanophycin (cphA) were significantly more abundant and highly expressed by Betaproteobacteria in non-saline water (Figs. 3a and 5, and Supplementary Figure 7), suggesting active storage and utilisation of cyanophycin granules.

Dissolved reactive phosphorus (DRP) concentrations were the highest in marine sediment pore water $(0.06 \mathrm{~g} /$ $\mathrm{m}^{3} \pm 0.03$ ), presumably owing to the naturally higher rate of phosphorus mobilisation in marine sediments [23], and were lowest in freshwater environments $(<0.01$ $\mathrm{g} / \mathrm{m}^{3}$, Fig. $1 \mathrm{~b}$ ). Phosphorus retention/release from sediment is complex, but is mainly controlled by increased desorption under saline conditions [88, 89]. Previous studies have shown that the high-affinity inorganic phosphate transporter pst system and phosphate regulon 


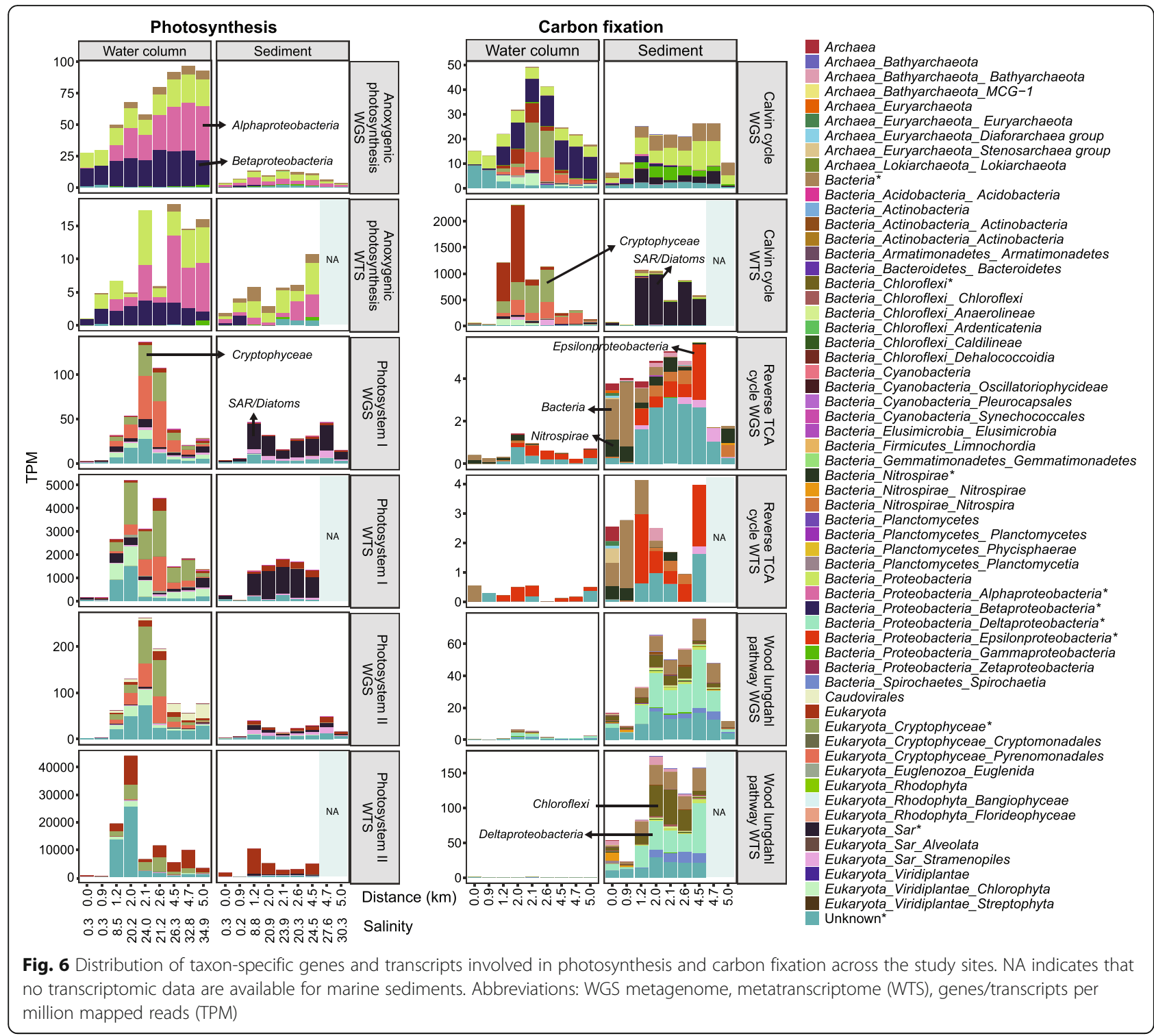

phoB-phoR (which regulates inorganic phosphate uptake) are highly upregulated under phosphate-limited conditions [90, 91]. Accordingly, data here shows that genes for phosphate uptake (pstSABC) and regulation (phol, phoB and $p h o R$ ) were negatively correlated with phosphate concentration $(\rho=-0.49, p<0.05)$ and were significantly more highly expressed in phosphate-limited non-saline water (Fig. 3 and Supplementary Figures 5 and 7)-primarily by Betaproteobacteria (Burkholderiales), which were highly abundant in this environment (Fig. 2a). Depending on phosphate availability, phoR can act as a kinase (phosphate-limited conditions) or phosphatase (phosphate-sufficient) and thereby activate or interrupt $p h o B$ phosphate regulation activity, respectively [91]. In phosphate-limited conditions, the phosphorylated $p h o B$ activates the high-affinity pst operon [90, 91].
Our results indicate a reliance on efficient phosphate uptake and regulation mechanisms in phosphate-limited freshwater.

\section{Nitrogen cycling dynamics across the salinity gradient}

Genes associated with nitrification and denitrification were predominantly expressed in brackish sediments (Fig. 5), corresponding with higher total organic carbon (TOC), total nitrogen (TN) and total recoverable phosphorus (TRP) concentrations (Fig. 1b). Results indicate that metabolic coupling between distinct taxa, to oxidise ammonia fully to nitrate, was far more common than organisms undertaking comammox along the transect (Supplementary Figure 8). We detected relatively low expression of amoA genes involved in comammox by the class Nitrospira (the genus Nitrospira is well known for 
nitrification and comammox [92]) at a single benthic freshwater site $(0.9 \mathrm{~km}$ along the transect, Supplementary Figure 8), where nitrate was highest and ammonium concentration was lowest (Fig. 1b). In contrast, genes involved in nitrification via ammonia oxidation to nitrite (amoA in archaea) and nitrite oxidation (nxrAB in Nitrospirae) were highly expressed in the brackish sediments (Fig. 5 and Supplementary Figure 8). The relative abundances of ammonia-oxidising bacteria and archaea can vary in coastal and estuarine sediments, depending on the environmental conditions (salinity, oxygen and ammonium concentration) [93-95]. Although archaea constituted only a minor fraction of the overall microbiome (Fig. 2a), gene expression data indicates they were the primary ammonia oxidiser in brackish sediments and are important contributors to estuarine biogeochemical cycling.

As for nitrification, genes related to nitrous oxide reduction (nosD, nos $Z$ ), the final step of the denitrification pathway, were predominantly expressed in brackish sediments (Fig. 4) and were primarily associated with Bacteroidetes (Fig. 5 and Supplementary Figure 8). Results therefore suggest a strong coupling of nitrification and denitrification in brackish sediments, leading to nitrogen loss from this estuary. Steep redox gradients promote the co-occurrence of aerobic and anaerobic metabolic pathways, including the aforementioned dark carbon fixation reactions and coupled nitrification-denitrification [31, 96]. Such a gradient may be expected in brackish sediments given the combination of high mud and organic carbon contents (Fig. $1 \mathrm{~b}$ and Supplementary Table 4 ), which are associated with hypoxic/anoxic conditions due to lower diffusion [97] and rapid consumption of oxygen within sediments, combined with oxygen generated by photosynthesizing diatoms at the sedimentwater interface (Figs. 5 and 6).

Unlike denitrification, dissimilatory nitrate reduction to ammonium (DNRA) retains bioavailable nitrogen [98]. The first two steps in denitrification and DNRA are nitrate and nitrite reduction, of which the second step involves distinct nitrite reductase enzymes (NirKS for denitrification; NirBD/NrfA for DNRA) [99]. Results show that DNRA genes (nrfA, nrfH) were highly expressed in non-saline sediment (Fig. 4 and Supplementary Figure 8). The ratio of denitrification-nos $Z$ to DNRA-nrfA gene expression in freshwater sediment (ratio $=0.06$ ) was on average 20 times lower than in brackish sediment (ratio $=1.56$, Supplementary Table 6), suggesting a partitioning between DNRA in freshwater sediment and denitrification in brackish sediment. Previous studies have found that a higher ratio of organic carbon (electron donor) to nitrate and a greater supply of nitrate relative to nitrite favour DNRA over denitrification [78, 100-102]. However, we did not find any relationship between carbon/nitrate or nitrate/nitrite ratios and DNRA-related gene expression in sediment (Supplementary Table 6). Although nitrate/nitrite ratios decreased across the transect (primarily due to a corresponding decrease in nitrate), nitrate concentrations were on average over ten times higher for most brackish sediment (ratios 4-34, distances $\leq 2.6 \mathrm{~km}$ along the transect) (Fig. 1b and Supplementary Table 4). This suggests that other unmeasured factors, such as sulfide concentrations or microbial generation times [100, 103], may instead have influenced denitrifier and DNRA activity.

\section{Sulfur metabolism was most active in the brackish-marine environment}

Like nitrification-denitrification, genes for sulfur metabolism, including sulfur reduction (cysN, sat and aprA for sulfate; $d s r A B D$ for sulfite) and oxidation ( $\mathrm{r} d s r A B$ for sulfur), were significantly more highly expressed in brackish sediments (Fig. 3a, Supplementary Figures 910). Expression was concomitant with highly abundant Gammaproteobacteria and Deltaproteobacteria capable of oxidising sulfur and reducing sulfate, respectively (Figs. 2a and 5). This is consistent with greater sulfide accumulation in brackish sediments owing to high mud and limited oxygen diffusion [30]. Taken together, these results reinforce the findings of studies indicating the brackish environment is a hotspot for biogeochemical cycling $[104,105]$. However, the expression of thiosulfate oxidation genes (soxBCY) by Alphaproteobacteria was significantly higher in marine water (LDA score $\geq 2$, Fig. $3 \mathrm{a}$ and Supplementary Figure 9) and positively correlated with high sulfate concentrations typical of marine water ( $\rho=0.76, p<0.05$; Fig. $1 \mathrm{~b}$ and Supplementary Figure 5). Thiosulfate can serve as an electron donor for anoxygenic photosynthesis [106] and be oxidised to sulfate via the Sox pathway [107]. Bacterial groups that perform aerobic anoxygenic photosynthesis (AAP), including alpha-, beta- and gamma-proteobacteria, are widely distributed in the surface ocean [108, 109]. Greater expression of genes related to thiosulfate oxidation (Supplementary Figure 9) and anoxygenic photosynthesis (pufLM) by planktonic marine Alphaproteobacteria (Figs. 5 and 6) suggests these bacteria may have coupled thiosulfate oxidation with photoheterotrophy in relatively carbon-limited marine water (DNPOC 1.7 versus $2.2 \mathrm{~g} / \mathrm{m}^{3}$ in brackish water) [110].

\section{Conclusions}

Across the river-marine transect, in a tidal lagoon setting, the microbial community and diversity were dominated by bacteria. Contrasting diversity trends were observed between the water column and sediments, and between prokaryotes and microeukaryotes, reflecting the 
strong geochemical differences between these environments, and the distinct physiologies and ecosystem roles of these taxa groups. While archaea and microeukaryotes represented only a minor fraction of the overall communities, they played significant roles in ammonia oxidation and photosynthesis, respectively. Microorganisms employed distinct osmoregulation strategies between freshwater and saline habitats by actively expressing diverse osmoregulation genes encoding potassium, sodium and glycine betaine transporters across the transect. Results indicate a significant predominance of phosphate acquisition in non-saline water, along with microeukaryotic-driven primary production, and prokaryotic nitrification-denitrification and sulfur metabolism in the brackish sediments, corresponding with large differences in resource availability. Overall, our study demonstrates that differences in salinity and nutrients impose significant biological boundaries between sediment and water, and among non-saline, brackish and marine environments.

\section{Materials and methods Sampling strategy}

Sampling was undertaken on 12 November 2018 within a low tide period. Nine sites (sites 1-9, Fig. 1a; site photos, Supplementary Figure 11) were selected covering a freshwater-to-marine salinity $(S)$ gradient $(0.2<S<35)$ across a 5-km-long transect of the Waiwera river and estuary, north of Auckland, New Zealand (36 33' 02.4" S, $\left.174^{\circ} 39^{\prime} 08.1^{\prime \prime} \mathrm{E}\right)$. For molecular analyses, at least $10 \mathrm{~L}$ of water was collected between 0.2 and $1 \mathrm{~m}$ below the surface of all sites and sequentially filtered through sterile $1.2-\mu \mathrm{m}$ and $0.22-\mu \mathrm{m}$ mixed cellulose ester filters (Merck Millipore, MA, USA). Triplicate water samples (unfiltered) were similarly collected in polyethylene bottles for chemical analysis at Hill Laboratories (Hamilton, New Zealand). The top $2 \mathrm{~cm}$ of sediment was collected at three locations approximately $5 \mathrm{~m}$ apart at each site and wet sieved through a $1-\mathrm{mm}$ mesh sieve to remove stones, plant material and macrofauna. All filter and sediment samples for molecular analyses were immediately preserved with LifeGuard Soil Preservation Solution (Qiagen, MD, USA) in sterile 50-mL Falcon tubes (1:3 wet sediment-to-LifeGuard ratio, individual water samples were filtered and preserved within 5-10 $\mathrm{min}$ of sample collection) and stored at $-80{ }^{\circ} \mathrm{C}$ until extraction. Samples for mud content and chemical analyses were stored at $4{ }^{\circ} \mathrm{C}$.

\section{Mud content measurement}

Sediment samples were oven dried at $105{ }^{\circ} \mathrm{C}$ for $12 \mathrm{~h}$ prior to sieving. Sediments were serially sieved using mesh sizes ranging from $1 \mathrm{~mm}$ to $63 \mu \mathrm{m}$ with a sieve shaker. Fractions retained on each mesh were weighed to determine mud and sand contents. Mud (clay and silt) and sand are identified as sediment with sizes of $<63 \mu \mathrm{m}$ and $>63 \mu \mathrm{m}$, respectively [111]. Mud content was calculated as follows: the weight of mud fraction/weight of sediments from all fractions $\times 100 \%$.

\section{Physiochemical and nutrient analyses}

Temperature, $\mathrm{pH}$ and salinity were measured on-site using a Pocket Pro+ Multi 2 Tester (HACH, CO, USA). All sediment and water samples were sent to Hill Laboratories (Hamilton, New Zealand) for processing. All nutrients were measured according to standard American Public Health Association (APHA) protocols [112]. TRP, TS, TN and TOC were only measured from sediment samples. All other nutrients were measured from water column and sediment pore water samples. Briefly, sediment TOC, following pre-treatment with acid to remove carbonates, was analysed using an Elementar Vario MAX Combustion Analyser (Langenselbold, Germany) with catalytic combustion (at $900{ }^{\circ} \mathrm{C}$ ) and $\mathrm{TN}$ was measured via an Lachat Quikchem Series 2 Flow injection Analyser (Lachat Instruments, CO, USA). Total sulfur was measured using a LECO SC-32 Sulfur Determinator (MI, USA), and TRP was analysed using a Aquakem Konelab 600 Discrete Analyser (Thermo Fisher Scientific, MA, USA). Water samples were prefiltered through $0.45-\mu \mathrm{m}$ membrane filters and saline samples diluted prior to analyses. Total ammonical-N, nitrate, nitrite and DRP were measured via a Lachat Quikchem Series 2 flow injection analyser (Lachat Instruments, CO, USA). Sulfate was analysed using a Dionex Ion Chromatography system (Sunnyvale, CA, USA). Samples for DNPOC were acidified to remove inorganic $C$ before addition of persulfate, heating to a temperature of above $375{ }^{\circ} \mathrm{C}$ and analysis via a Sievers Innovox TOC analyser (SUEZ Analytical Instruments, CO, USA). River turbidity data, collected by Auckland Council at GPS coordinates $36^{\circ} 33^{\prime}$ 01.4" S $174^{\circ} 39^{\prime} 59.3^{\prime \prime} \mathrm{E}$, were obtained from the Land, Air, Water Aotearoa (https://www.lawa.org.nz/ ).

\section{Nucleic acid extraction and sequencing}

Both RNA and DNA were co-extracted using RNeasy PowerSoil Total RNA Kits and RNeasy PowerSoil DNA Elution Kits (Qiagen, MD, USA). Total RNA and DNA from each sample were isolated from 2-8 $\mathrm{g}$ of sediment or $1-5 \mathrm{~g}$ of filter (1/3-1 filter, 10L water per filter) with collected planktonic biomass (both $1.2 \mu \mathrm{m}$ and $0.22 \mu \mathrm{m}$ combined). Extracted nucleic acids were stored at -80 ${ }^{\circ} \mathrm{C}$. RNA samples were treated with DNaseI. DNA removal was verified by PCR amplification of the $16 \mathrm{~S}$ rRNA genes using 515F/806R primers [113, 114], JumpStart REDTaq Readymix (Sigma-Aldrich, MO, USA) and $2 \mu \mathrm{L}$ of the template (sample or positive control), under 
the following conditions: $95{ }^{\circ} \mathrm{C}$ for $5 \mathrm{~min}$; 55 cycles: 95 ${ }^{\circ} \mathrm{C}$ for $45 \mathrm{~s}, 50{ }^{\circ} \mathrm{C}$ for $60 \mathrm{~s}, 72{ }^{\circ} \mathrm{C}$ for $90 \mathrm{~s} ; 72{ }^{\circ} \mathrm{C}$ for 10 min. Visualisation by gel electrophoresis was used to confirm no amplification in DNase-treated samples. RNA was purified using RNA Clean \& Concentrator-5 Kits (Zymo Research, CA, USA). DNA extracts were further purified by mixing with nuclease-free $0.3 \mathrm{M}$ sodium acetate (final concentration; Sigma-Aldrich, MO, USA) and $0.1 \mu \mathrm{g} / \mu \mathrm{L}$ glycogen (final concentration) and reprecipitating with 2:1 volumes of cold ethanol following incubation for $30 \mathrm{~min}$ at $-20{ }^{\circ} \mathrm{C}$. Pellets were washed with $70 \%$ ethanol and re-eluted in nuclease-free water. High molecular weight DNA was confirmed via gel electrophoresis. DNA and RNA concentrations and quality were further assessed using a Nanodrop 2000c Spectrophotometer (Thermo Fisher Scientific, MA, USA) and also, for RNA, an Agilent 2100 Bioanalyzer (Agilent Technologies, CA, USA) using the Agilent RNA 6000 Nano Kit. Low-quality RNA extracts (without obvious $16 \mathrm{~S} / 23 \mathrm{~S}$ peaks in bioanalyzer electropherogram) from sandy sediment at marine sites 8 and 9 were excluded from further analysis. The remaining 36 DNA and 30 RNA extracts were prepared for metagenomic and metatranscriptomic sequencing. Prior to RNA library preparation, ribosomal RNAs were depleted using the Ovation Universal Prokaryotic RNASeq, Prokaryotic AnyDeplete (TECAN, Zürich, Switzerland) system, according to the manufacturer's instructions. Library preparation and sequencing were undertaken by the Otago Genomics Facility (University of Otago, Dunedin, New Zealand). Metagenome libraries were prepared using the Illumina TruSeq DNA Nano kit (with 550-bp insert sizes). Metatranscriptome libraries were prepared using the Ovation Complete Prokaryotic RNASeq kit. Paired-end $2 \times 250$ bp sequencing for DNA (over 14 lanes) and $2 \times 125 \mathrm{bp}$ sequencing for RNA (over 14 lanes) were performed using the Illumina HiSeq 2500 platform with V2 (DNA) and V4 (RNA) chemistry. All sequence data have been deposited with NCBI under BioProject PRJNA668816.

\section{Sequence read processing}

Ribosomal RNA reads were first removed from metatranscriptomes using SortMeRNA v2.1 [115] with bacterial, archaeal and eukaryotic rRNA databases, and results were passed to repair.sh (BBMap [116]) to regenerate paired-end reads. Metagenomic and non-ribosomal metatranscriptomic read quality was inspected using FastQC [117]. Reads were trimmed using Trimmomatic v0.38 [118] with a minimum Phred score of 30 and adapter sequence removal via the ILLUMINACLIP option with Illumina universal adapter sequence (AGATCGGAAGAG). Reads were also trimmed to a maximum of $240 \mathrm{bp}$ (DNA) and $115 \mathrm{bp}$ (RNA) long to remove additional low-quality bases, and reads $<80 \mathrm{bp}$
(DNA) and $<60$ bp (RNA) long were discarded. A sediment sample from site 9, replicate 1 (S9R1), was subjected to additional trimming (headcrop 10) due to low base quality.

\section{Small subunit (SSU) rRNA gene reconstruction}

Near full-length $16 \mathrm{~S}$ and $18 \mathrm{~S}$ rRNA gene sequences were reconstructed from each metagenome, over 50 iterations and using a joining threshold of 97\%, with EMIRGE [119] and the SILVA SSU Ref NR 99138 database. We detected and removed 2670 chimeras with the uchime ref command [120]. Sequences from across samples were concatenated and clustered into OTUs (97\% threshold) with UCLUST [120], then rarefied to 3343 sequences per sample, resulting in a total of 7334 unique OTUs with a minimum count across samples $\geq 2$ (Supplementary Table 7). SSU rRNA gene relative abundances were based on normalised priors from the final EMIRGE iteration.

\section{Metagenome assembly, taxonomic and functional annotations}

Trimmed reads from individual water samples or from spatial triplicate sediment samples from the same site were assembled or co-assembled, respectively, using metaSPAdes [121] with k-mer values: 41, 61, 81, 101 and 127, resulting in 143 million contigs (Supplementary Figure 12). A k-mer-based profiler, Kraken2 v2.1.2 [122], was used to assign taxonomy to the trimmed reads based on compositional similarity to publicly available genome databases from RefSeq [123]. Species relative abundances were further estimated using a Bayesian approach with Bracken v2.6.0 [124]. Data were rarefied to $2,543,737$ reads per sample, and species belonged to Streptophyta and Chordata were removed, resulting in a total of 5136 unique species (Supplementary Table 8). Open reading frames (ORFs) were predicted and translated into protein sequences using Prodigal v2.6.3 [125]. Protein sequences were searched against a library of hidden Markov models (HMMs) consisting of TIGRFAMs [126], Pfam [127] and custom HMMs for metabolic pathways using HMMER3 [128]. Marker genes for the pathway of interest and the cut-off values for HMM scores were derived from Anantharaman et al. [129], Pfam [127], TIGRFAM [126] and FunGene [130] databases (Supplementary Table 9). Phylogenetic analyses were conducted on concatenated $\operatorname{ds} A B$ genes to further classify them into $d s r A B$ (in sulfate/sulfite-reducing bacteria) and $r d s r A B$ (in sulfur-oxidising bacteria) using FastTree v2.1.10 [131]. Reference protein sequences for phylogenetic analyses were obtained by BLAST searches against the NCBI nr protein database [132]. Taxonomic affiliations of functionally annotated genes were assigned with DIAMOND BLASTP [133] with default settings 
against the NCBI nr protein database (downloaded on 16 February 2020), using a weighted lowest common ancestor (LCA) approach. We retained only hits with at least $70 \%$ query coverage, $80 \%$ identity and bit scores within $5 \%$ of the top hit for LCA identification.

\section{Metagenome and metatranscriptome read mapping and counts}

DNA and RNA (non-rRNA) reads were mapped back to metagenomic contigs using BBMap v37.93 [116] with default parameters. Read counts were calculated for each predicted open reading frame (ORF) using featureCounts v2.0.0 [134]. Gene and transcript counts were normalised using gene or transcript per million mapped reads (TPM) to measure the bulk contribution of the community $[135,136]$. TPM $=$ (number of reads mapped to the gene/gene length)/sum (number of reads mapped to the gene/gene length) $\times 1,000,000$.

\section{Statistical analyses}

Unless otherwise stated, the following statistical analyses were carried out in $\mathrm{R}$ environment version 3.5.1 [137]. Shannon-Wiener indices, Simpson's indices and relative OTU richness were determined using the vegan package [138] and the rarefied OTU table combining reconstructed $16 \mathrm{~S}$ and $18 \mathrm{~S}$ rRNA genes. A Wilcoxon signedrank test was performed to determine significant differences in observed diversity between the water column and sediment. Distance-decay relationships for microbial communities and functional gene groups were constructed by first calculating pairwise Bray-Curtis dissimilarities among sites using the vegdist function in the vegan package [138], and fitting negative exponential functions via a log-linked generalised linear model (GLM) or local polynomial regression (LOESS) model. NMDS ordinations were plotted based on Bray-Curtis dissimilarities, and environmental variables were fitted with 999 Monte Carlo permutation tests using the vegan package [138]. Pairwise permutational multivariate analyses of variance (PERMANOVA) with BenjaminiHochberg corrections were carried out to test for statistically significant variance among multivariate microbial community data using the pairwiseAdonis package [139]. Spearman's correlation coefficients between the relative abundances of specific taxa and environmental parameters were calculated using the $\mathrm{R}$ cor function. Taxa with $p<0.05$ were determined to be significantly correlated with the environmental parameters. The bioenv function in R's vegan package [138] was used with Spearman's rank correlations to search over subsets of the continuous environmental variables to determine the best explanatory variables for community composition. A multivariate regression tree was plotted using mvpart package [140], with 1000 cross-validations and tree size $=8$ to identify the main predictors that correlate with microbial community structure. As both salinity and distance were highly correlated and exhibited multicollinearity, we used salinity (and excluded distance) as one of the predictor variables for the analysis. The decision tree identifies variance in microbial community composition (Bray-Curtis dissimilarity) caused by threshold values of key site physicochemical attributes. The values attached to each branch of the tree mark the physicochemical criteria used by the regression tree to group samples based on differences in community composition.

The correlation between gene and transcript relative abundances was measured using the $\mathrm{R}$ cor.test function. Mantel tests were run to assess Spearman's correlations between functional and taxonomic community dissimilarity matrices based on Bray-Curtis dissimilarities. LEfSe was applied to metagenomic and metatranscriptomics data to identify environment-associated metabolic functions by utilising Kruskal-Wallis and Wilcoxon rank-sum tests to determine variations occurring between and within environments with a linear discriminant analysis (LDA) score of $\geq 2$ [141]. To determine co-expressed genes associated with environmental parameters, weighted correlation network analysis was also performed using transcript counts normalised by TPM as input data to find clusters of highly correlated gene transcripts by using WGCNA package [142] with minimum module size $=5$ and softthresholding power $=14\left(R^{2}=0.81\right)$ to relate the functions or modules to one another and to environmental parameters.

\section{Supplementary Information}

The online version contains supplementary material available at https://doi. org/10.1186/s40168-021-01145-3.

Additional file 1. Supplementary tables.

Additional file 2. Supplementary results and discussion, and figures.

\begin{abstract}
Acknowledgements
Computational resources were provided by New Zealand eScience Infrastructure. We thank B Weir (Landcare Research) and C Astudillo-García, JS Boey, O Mosley and E Gios (University of Auckland) for assisting in sample collection and M Hoggard (University of Auckland) for manuscript edits.
\end{abstract}

\section{Authors' contributions}

$\mathrm{KMH}, \mathrm{DW}, \mathrm{GL}$ and HST designed the study and collected the samples. HST and DW prepared samples for sequencing and nutrient measurements. HST and DW processed and analysed the data. HST, KMH and GL wrote the manuscript. All authors read and approved the final manuscript.

\section{Funding}

This research was supported by Genomics Aotearoa (project 1806), a New Zealand Ministry of Business, Innovation, and Employment-funded research platform (http://www.genomics-aotearoa.org.nz/). 


\section{Availability of data and materials}

The data generated in the current study are all publicly available. All sequence data have been deposited with NCBI under BioProject PRJNA668816. R scripts for plotting figures and statistical analyses are available at https://github.com/HweeSze/Waiwera_manuscript_plots.

\section{Declarations}

\section{Ethics approval and consent to participate}

Not applicable.

\section{Consent for publication}

Not applicable.

\section{Competing interests}

The authors declare that they have no competing interests.

\section{Author details}

${ }^{1}$ School of Biological Sciences, University of Auckland, Auckland 1010, New Zealand. ${ }^{2}$ Current address: Ministry for Primary Industries, Auckland, New Zealand.

Received: 30 May 2021 Accepted: 2 August 2021

Published online: 20 September 2021

\section{References}

1. Allan JD, Ibañez Castillo MM. Stream ecology: structure and function of running waters. 2nd ed. Dordrecht: Springer; 2007. https://doi.org/10.1007/ 978-1-4020-5583-6.

2. Heinrichs ME, Mori C, Dlugosch L. Complex interactions between aquatic organisms and their chemical environment elucidated from different perspectives. In: Jungblut S, Liebich V, Bode-Dalby M, editors. YOUMARES 9 - Oceans Our Res Our Future. Cham: Springer; 2020. p. 279-97. https://doi. org/10.1007/978-3-030-20389-4_15.

3. Cloern JE, Jassby AD, Schraga TS, Nejad E, Martin C. Ecosystem variability along the estuarine salinity gradient: examples from long-term study of San Francisco Bay. Limnol Oceanogr. 2017;62(S1):272-91. https://doi.org/10.1 002/Ino.10537.

4. Remane A. Die brackwasserfauna. Verh Dt Zool Ges. 1934;36:34-74

5. Filker S, Kühner S, Heckwolf M, Dierking J, Stoeck T. A fundamental difference between macrobiota and microbial eukaryotes: protistan plankton has a species maximum in the freshwater-marine transition zone of the Baltic Sea. Environ Microbiol. 2019;21(2):603-17. https://doi.org/1 $0.1111 / 1462-2920.14502$

6. Herlemann DP, Labrenz M, Jürgens K, Bertilsson S, Waniek JJ, Andersson AF. Transitions in bacterial communities along the $2000 \mathrm{~km}$ salinity gradient of the Baltic Sea. ISME J. 2011;5(10):1571-9. https://doi.org/10.1038/ismej.2 011.41.

7. Herlemann DPR, Lundin D, Andersson AF, Labrenz M, Jürgens K Phylogenetic signals of salinity and season in bacterial community composition across the salinity gradient of the Baltic Sea. Front Microbiol. Frontiers. 2016:7:1883.

8. Wang J, Yang D, Zhang Y, Shen J, van der Gast C, Hahn MW, et al. Do patterns of bacterial diversity along salinity gradients differ from those observed for macroorganisms? PLoS One. Public Library Sci. 2011;6(11): e27597. https://doi.org/10.1371/journal.pone.0027597.

9. Lozupone CA, Knight R. Global patterns in bacterial diversity. Proc Natl Acad Sci. 2007;104(27):11436-40. https://doi.org/10.1073/pnas.0611525104

10. Thompson LR, Sanders JG, McDonald D, Amir A, Ladau J, Locey KJ, et al. A communal catalogue reveals earth's multiscale microbial diversity. Nature. Nature Publishing Group. 2017;551:457-63.

11. Mason OU, Canter EJ, Gillies LE, Paisie TK, Roberts BJ. Mississippi River plume enriches microbial diversity in the Northern Gulf of Mexico. Front Microbiol. Frontiers. 2016;7:1048.

12. Doherty M, Yager PL, Moran MA, Coles VJ, Fortunato CS, Krusche AV, et al Bacterial biogeography across the Amazon river-ocean continuum. Front Microbiol. Frontiers. 2017:8:882.

13. Dupont CL, Larsson J, Yooseph S, Ininbergs K, Goll J, Asplund-Samuelsson J, et al. Functional tradeoffs underpin salinity-driven divergence in microbial community composition. PLoS One. Public Library of Science. 2014:9: e89549.
14. Fortunato CS, Crump BC. Microbial gene abundance and expression patterns across a river to ocean salinity gradient. PLoS One. 2015;10(11): e0140578. https://doi.org/10.1371/journal.pone.0140578.

15. Walsh DA, Lafontaine J, Grossart H-P. On the eco-evolutionary relationships of fresh and salt water bacteria and the role of gene transfer in their adaptation. In: Gophna U, editor. Lateral Gene Transf Evol. New York: Springer; 2013. p. 55-77. https://doi.org/10.1007/978-1-4 614-7780-8_3

16. Henson MW, Lanclos VC, Faircloth BC, Thrash JC. Cultivation and genomics of the first freshwater SAR11 (LD12) isolate. ISME J. Nature Publishing Group. 2018:12:1846-60.

17. Oren A. Life at high salt concentrations. In: Rosenberg $E_{1}$ DeLong EF, Lory S, Stackebrandt E, Thompson F, editors. The prokaryotes. 4th ed. Berlin: Springer; 2013. p. 421-40. https://doi.org/10.1007/978-3-642-3 0123-0_57.

18. Trchounian A, Kobayashi $\mathrm{H}$. Kup is the major $\mathrm{K}^{+}$uptake system in Escherichia coli upon hyper-osmotic stress at a low pH. FEBS Lett. 1999:447(2-3):144-8. https://doi.org/10.1016/S0014-5793(99)00288-4.

19. Trchounian A, Kobayashi H. $\mathrm{K}^{+}$uptake by fermenting Escherichia coli cells: $\mathrm{pH}$ dependent mode of the TrkA system operating. Biosci Rep. 2000;20(4): 277-88. https://doi.org/10.1023/A:1026493024066.

20. Bañuelos MA, Klein RD, Alexander-Bowman SJ, Rodríguez-Navarro A. A potassium transporter of the yeast Schwanniomyces occidentalis homologous to the Kup system of Escherichia coli has a high concentrative capacity. EMBO J. 1995;14(13):3021-7. https://doi.org/10.1002/j.1460-2075.1 995.tb07304.x.

21. Rhoads DB, Waters FB, Epstein W. Cation transport in Escherichia coli. VIII. Potassium transport mutants. J Gen Physiol. 1976;67(3):325-41. https://doi. org/10.1085/jgp.67.3.325

22. Paver SF, Muratore D, Newton RJ, Coleman ML. Reevaluating the salty divide: phylogenetic specificity of transitions between marine and freshwater systems. Flynn TM, editor. mSystems. 2018;3:e00232-18.

23. Caraco N, Cole J, Likens GE. A comparison of phosphorus immobilization in sediments of freshwater and coastal marine systems. Biogeochemistry. 1990; 9(3):277-90. https://doi.org/10.1007/BF00000602.

24. Xia X, Zhang S, Li S, Zhang L, Wang G, Zhang L, et al. The cycle of nitrogen in river systems: sources, transformation, and flux. Environ Sci Process Impacts. 2018;20(6):863-91. https://doi.org/10.1039/C8EM00042E.

25. Berner RA. Sedimentary pyrite formation. Am J Sci. 1970;268(1):1-23. https:// doi.org/10.2475/ajs.268.1.1.

26. Emeis KC, Struck U, Leipe T, Pollehne F, Kunzendorf H, Christiansen C. Changes in the C, N, P burial rates in some Baltic Sea sediments over the last 150 years - relevance to $P$ regeneration rates and the phosphorus cycle. Mar Geol. Elsevier. 2000;167(1-2):43-59. https://doi.org/10.1016/S0025-322 7(00)00015-3.

27. Mcdowell RW, Larned ST, Houlbrooke DJ. Nitrogen and phosphorus in New Zealand streams and rivers: control and impact of eutrophication and the influence of land management. N Z J Mar Freshw Res. 2009;43(4):985-95. https://doi.org/10.1080/00288330909510055.

28. Cloern JE, Foster SQ, Kleckner AE. Phytoplankton primary production in the world's estuarine-coastal ecosystems. Biogeosciences. 2014;11(9):2477-501. https://doi.org/10.5194/bg-11-2477-2014.

29. Andersson A, Brugel S, Paczkowska J, Rowe OF, Figueroa D, Kratzer S, et al. Influence of allochthonous dissolved organic matter on pelagic basal production in a northerly estuary. Estuar Coast Shelf Sci. 2018;204:225-35. https://doi.org/10.1016/j.ecss.2018.02.032.

30. Hargrave BT, Holmer M, Newcombe CP. Towards a classification of organic enrichment in marine sediments based on biogeochemical indicators. Mar Pollut Bull. 2008;56(5):810-24. https://doi.org/10.1016/j.marpolbul.2008.02. 006.

31. An S, Joye SB. Enhancement of coupled nitrification-denitrification by benthic photosynthesis in shallow estuarine sediments. Limnol Oceanogr. 2001;46(1):62-74. https://doi.org/10.4319/lo.2001.46.1.0062.

32. Holland KR, Kleinmans A, Hussain E. State of the environment monitoring: river water quality annual report 2016. New Zealand: Auckland Council; 2018. p. 1-57. Report No.: TR2018/003

33. Kennish MJ. Estuaries, anthropogenic impacts. In: Schwartz ML, editor. Encycl Coast Sci. Dordrecht: Springer Netherlands; 2005. p. 434-6.

34. Kennish MJ. Environmental threats and environmental future of estuaries. Environ Conserv. Cambridge University Press. 2002;29(1):78-107. https://doi. org/10.1017/S0376892902000061. 
35. Hume T, Gerbeaux P, Hart D, Kettles H, Neale D. A classification of New Zealand's coastal hydrosystems. New Zealand: Ministry of the Environment; 2016. Report No.: HAM2016-062

36. Onuf CP. Laguna Madre. In: Handley L, Altsman D, DeMay R, editors. Seagrass status trends North Gulf Mex 1940-2002. 1.0. Reston: U.S. Dept. of the Interior, U.S. Geological Survey; 2007. p. 29-40.

37. Dame R, Alber M, Allen D, Mallin M, Montague C, Lewitus A, et al. Estuaries of the South Atlantic Coast of North America: their geographical signatures. Estuaries. 2000;23(6):793-819. https://doi.org/10.2307/1352999.

38. John SE, Rajimol TR, Mohan SV, Maya K, Padmalal D. Environmental degradation of a tropical estuary due to human interferences - a case study from southern Kerala, SW India. Arab J Geosci. 2017;10(16):352. https://doi. org/10.1007/s12517-017-3112-z.

39. Cromwell JE. Barrier coast distribution: a world-wide survey. Abstr Vol 2nd Natl Coast Shallow Water Res Conf. 2nd ed., Los Angeles, C.A.: University Press, University of Southern California; 1971. p. 50

40. Mclay C. An inventory of the status and origin of New Zealand estuarine systems. Proc N Z Ecol Soc. 1976;23:8-26.

41. Davidson NC. Estuaries of Great Britain. In: Finlayson CM, Milton GR, Prentice RC, Davidson NC, editors. Wetl Book II Distrib Descr Conserv. Dordrecht: Springer Netherlands; 2018. p. 997-1009. https://doi.org/10.1007/978-94007-4001-3_3.

42. Liu T, Zhang AN, Wang J, Liu S, Jiang $X$, Dang C, et al. Integrated biogeography of planktonic and sedimentary bacterial communities in the Yangtze River. Microbiome. 2018;6(1):16. https://doi.org/10.1186/s40168-0170388-X.

43. Kong J, Wang Y, Warren A, Huang B, Sun P. Diversity distribution and assembly mechanisms of planktonic and benthic microeukaryote communities in intertidal zones of Southeast Fujian, China. Front Microbiol. Frontiers. 2019;10:2640

44. Griffiths JR, Kadin M, Nascimento FJA, Tamelander T, Törnroos A, Bonaglia S, et al. The importance of benthic-pelagic coupling for marine ecosystem functioning in a changing world. Glob Change Biol. 2017;23(6):2179-96. https://doi.org/10.1111/gcb.13642

45. van der Lee GH, Kraak MHS, Verdonschot RCM, Vonk JA, Verdonschot PFM. Oxygen drives benthic-pelagic decomposition pathways in shallow wetlands. Sci Rep. Nature Publishing Group. 2017;7:1-8.

46. Mansfeldt C, Achermann S, Men Y, Walser J-C, Villez K, Joss A, et al. Microbial residence time is a controlling parameter of the taxonomic composition and functional profile of microbial communities. ISME J. 2019; 13(6):1589-601. https://doi.org/10.1038/s41396-019-0371-6.

47. Ohrel RL, Register KM. Chapter 14 Salinity. Volunt Estuary Monit Methods Man. In: The United States of America: Environmental Protection Agency \& The Ocean Conservancy. 2nd ed; 2006. p. 219-28.

48. Hood RR, Coles VJ, Gross TF. Marine models. In: Jørgensen SE, Fath BD, editors. Encycl Ecol. Oxford: Academic; 2008. p. 2217-25. https://doi.org/10.1 016/B978-008045405-4.00186-5.

49. Telesh I, Schubert H, Skarlato S. Revisiting Remane's concept: evidence for high plankton diversity and a protistan species maximum in the horohalinicum of the Baltic Sea. Mar Ecol Prog Ser. 2011;421:1-11. https:// doi.org/10.3354/meps08928.

50. Louca S, Parfrey LW, Doebeli M. Decoupling function and taxonomy in the global ocean microbiome. Science. American Association for the Advancement of Science. 2016;353(6305):1272-7. https://doi.org/10.1126/ science.aaf4507.

51. Uritskiy G, Tisza MJ, Gelsinger DR, Munn A, Taylor J, DiRuggiero J. Cellular life from the three domains and viruses are transcriptionally active in a hypersaline desert community. Environ Microbiol. 2020;0(7):1-17. https://doi. org/10.1111/1462-2920.15023.

52. Louca S, Polz MF, Mazel F, Albright MBN, Huber JA, O'Connor Ml, et al. Function and functional redundancy in microbial systems. Nat Ecol Evol. Nature Publishing Group. 2018;2(6):936-43. https://doi.org/10.1038/s41559-018-0519-1.

53. Martiny AC, Treseder K, Pusch G. Phylogenetic conservatism of functional traits in microorganisms. ISME J. Nature Publishing Group. 2013;7:830-8.

54. Glibert P, Boynton W, Flemer D, Heil C, Sharp J, Hagy J III, et al. Nutrients in estuaries: a summary report of the National Estuaries Experts Workgroup, 2005-2007. U.S.A: U.S. Environmental Protection Agency; 2010.

55. Gunde-Cimerman N, Plemenitaš A, Oren A. Strategies of adaptation of microorganisms of the three domains of life to high salt concentrations. FEMS Microbiol Rev. Oxford Academic. 2018;42(3):353-75. https://doi.org/1 0.1093/femsre/fuy009.
56. Barquera B. The sodium pumping NADH:quinone oxidoreductase $\left(\mathrm{Na}^{+}-\right.$ NQR), a unique redox-driven ion pump. J Bioenerg Biomembr. 2014;46(4): 289-98. https://doi.org/10.1007/s10863-014-9565-9.

57. Hiramatsu T, Kodama K, Kuroda T, Mizushima T, Tsuchiya T. A putative multisubunit $\mathrm{Na}^{+} / \mathrm{H}^{+}$antiporter from Staphylococcus aureus. J Bacteriol. 1998;180(24):6642-8. https://doi.org/10.1128/JB.180.24.6642-6648.1998.

58. Vimont $\mathrm{S}$, Berche $\mathrm{P}$. NhaA, an $\mathrm{Na}^{+} / \mathrm{H}^{+}$antiporter involved in environmental survival of Vibrio cholerae. J Bacteriol. 2000;182(10):2937-44. https://doi.org/1 0.1128/JB.182.10.2937-2944.2000.

59. Mulkidjanian AY, Dibrov P, Galperin MY. The past and present of sodium energetics: may the sodium-motive force be with you. Biochim Biophys Acta BBA Bioenerg. 1777;2008(7-8):985-92. https://doi.org/10.1016/j.bbabio.2 008.04.028.

60. Lanyi JK. Salt-dependent properties of proteins from extremely halophilic bacteria. Bacteriol Rev. 1974;38(3):272-90. https://doi.org/10.1128/br.38.3.2 72-290.1974.

61. Vrbka L, Vondrášek J, Jagoda-Cwiklik B, Vácha R, Jungwirth P. Quantification and rationalization of the higher affinity of sodium over potassium to protein surfaces. Proc Natl Acad Sci. National Academy of Sciences. 2006; 103(42):15440-4. https://doi.org/10.1073/pnas.0606959103.

62. Oren A. Bioenergetic aspects of halophilism. Microbiol Mol Biol Rev. American Society for Microbiology. 1999;63(2):334-48. https://doi.org/10.112 8/MMBR.63.2.334-348.1999.

63. Noell SE, Giovannoni SJ. SAR11 bacteria have a high affinity and multifunctional glycine betaine transporter. Environ Microbiol. 2019;21(7): 2559-75. https://doi.org/10.1111/1462-2920.14649.

64. Antia NJ, Berland BR, Bonin DJ, Maestrini SY. Comparative evaluation of certain organic and inorganic sources of nitrogen for phototrophic growth of marine microalgae. J Mar Biol Assoc U K. 1975;55(3):519-39. https://doi. org/10.1017/S0025315400017239.

65. Taylor WR. Light and photosynthesis in intertidal benthic diatoms. Helgoländer Wiss Meeresunters. 1964;10(1-4):29-37. https://doi.org/10.1007/BF01626096.

66. Kjerfve B. Chapter 1 Coastal lagoons. In: Kjerfve B, editor. Coast Lagoon Process [Internet]: Elsevier; 1994. p. 1-8. Available from: https://www. sciencedirect.com/science/article/pii/S0422989408700060. https://doi.org/1 0.1016/S0422-9894(08)70006-0.

67. Keil RG, Tsamakis E, Fuh CB, Giddings JC, Hedges JI. Mineralogical and textural controls on the organic composition of coastal marine sediments: hydrodynamic separation using SPLITT-fractionation. Geochim Cosmochim Acta. 1994;58(2):879-93. https://doi.org/10.1016/0016-7037(94)90512-6.

68. Medeiros PM, Seidel M, Ward ND, Carpenter EJ, Gomes HR, Niggemann J, et al. Fate of the Amazon River dissolved organic matter in the tropical Atlantic Ocean. Glob Biogeochem Cycles. 2015;29(5):677-90. https://doi. org/10.1002/2015GB005115.

69. Prahl FG, Small LF, Eversmeyer B. Biogeochemical characterization of suspended particulate matter in the Columbia River estuary. Mar Ecol Prog Ser. 1997;160:173-84. https://doi.org/10.3354/meps160173.

70. Seidel M, Yager PL, Ward ND, Carpenter EJ, Gomes HR, Krusche AV, et al. Molecular-level changes of dissolved organic matter along the Amazon River-to-ocean continuum. Mar Chem. 2015;177:218-31. https://doi.org/10.1 016/j.marchem.2015.06.019.

71. Eyre BD, Ferguson AJP, Webb A, Maher D, Oakes JM. Metabolism of different benthic habitats and their contribution to the carbon budget of a shallow oligotrophic sub-tropical coastal system (southern Moreton Bay, Australia). Biogeochemistry. 2011;102(1-3):87-110. https:/doi.org/10.1007/s10533-010-9424-7.

72. Maher DT, Eyre BD. Carbon budgets for three autotrophic Australian estuaries: implications for global estimates of the coastal air-water $\mathrm{CO}_{2}$ flux. Glob Biogeochem Cycles. 2012;26:1-18.

73. Dyksma S, Bischof K, Fuchs BM, Hoffmann K, Meier D, Meyerdierks A, et al. Ubiquitous Gammaproteobacteria dominate dark carbon fixation in coastal sediments. ISME J. Nature Publishing Group. 2016;10:1939-53.

74. Santoro AL, Bastviken D, Gudasz C, Tranvik L, Enrich-Prast A. Dark carbon fixation: an important process in lake sediments. PLoS One. Public Library of Science. 2013;8:e65813.

75. Berg IA. Ecological aspects of the distribution of different autotrophic $\mathrm{CO}_{2}$ fixation pathways. Appl Environ Microbiol. American Society for Microbiology. 2011;77(6):1925-36. https://doi.org/10.1128/AEM.02473-10.

76. Lücker S, Wagner M, Maixner F, Pelletier E, Koch H, Vacherie B, et al. A Nitrospira metagenome illuminates the physiology and evolution of globally important nitrite-oxidizing bacteria. Proc Natl Acad Sci. National Academy of Sciences. 2010;107(30):13479-84. https://doi.org/10.1073/pnas.1003860107. 
77. Domingues RB, Barbosa AB, Sommer U, Galvão HM. Ammonium, nitrate and phytoplankton interactions in a freshwater tidal estuarine zone: potential effects of cultural eutrophication. Aquat Sci. 2011;73(3):331-43. https://doi. org/10.1007/s00027-011-0180-0.

78. Herbert RA. Nitrogen cycling in coastal marine ecosystems. FEMS Microbio Rev. 1999;23(5):563-90. https://doi.org/10.1111/j.1574-6976.1999.tb00414.x.

79. Jensen $\mathrm{MH}$, Lomstein $\mathrm{E}$, Ssrensen J. Benthic $\mathrm{NH}_{4}{ }^{+}$and $\mathrm{NO}_{3}{ }^{-}$flux following sedimentation of a spring phytoplankton bloom in Aarhus Bight, Denmark. Mar Ecol Prog Ser. 1990;61:87-96. https://doi.org/10.3354/meps061087.

80. Ghylin TW, Garcia SL, Moya F, Oyserman BO, Schwientek P, Forest KT, et al. Comparative single-cell genomics reveals potential ecological niches for the freshwater acl Actinobacteria lineage. ISME J. Nature Publishing Group. 2014:8:2503-16

81. Howarth RW, Marino R, Cole JJ. Nitrogen fixation in freshwater, estuarine, and marine ecosystems. 2. Biogeochemical controls ${ }^{1}$. Limnol Oceanogr. 1988;33:688-701.

82. Daesch G, Mortenson LE. Effect of ammonia on the synthesis and function of the $\mathrm{N}_{2}$-fixing enzyme system in Clostridium pasteurianum. J Bacteriol. 1972;110(1):103-9. https://doi.org/10.1128/jb.110.1.103-109.1972.

83. Drozd JW, Tubb RS, Postgate JR. A chemostat study of the effect of fixed nitrogen sources on nitrogen fixation, membranes and free amino acids in Azotobacter chroococcum. J Gen Microbiol. 1972;73(2):221-32. https://doi. org/10.1099/00221287-73-2-221.

84. Allen JF, Thake B, Martin WF. Nitrogenase inhibition limited oxygenation of earth's proterozoic atmosphere. Trends Plant Sci. 2019;24(11):1022-31. https://doi.org/10.1016/j.tplants.2019.07.007.

85. Paerl HW, Crocker KM, Prufert LE. Limitation of $\mathrm{N}_{2}$ fixation in coastal marine waters: relative importance of molybdenum, iron, phosphorus, and organic matter availability. Limnol Oceanogr. 1987;32(3):525-36. https://doi.org/1 0.4319/lo.1987.32.3.0525

86. Raven JA. The iron and molybdenum use efficiencies of plant growth with different energy, carbon and nitrogen sources. New Phytol. 1988;109(3):27987. https://doi.org/10.1111/j.1469-8137.1988.tb04196.x.

87. Watzer B, Forchhammer K. Cyanophycin synthesis optimizes nitrogen utilization in the unicellular cyanobacterium Synechocystis sp. PCC 6803. Appl Environ Microbiol. 2018;84(20):e01298-18. https://doi.org/10.1128/AEM. 01298-18.

88. Gardolinski PCFC, Worsfold PJ, McKelvie ID. Seawater induced release and transformation of organic and inorganic phosphorus from river sediments. Water Res. 2004;38(3):688-92. https://doi.org/10.1016/j.wa tres.2003.10.048.

89. Howarth R, Chan F, Conley DJ, Garnier J, Doney SC, Marino R, et al. Coupled biogeochemical cycles: eutrophication and hypoxia in temperate estuaries and coastal marine ecosystems. Front Ecol Environ. 2011;9(1):18-26. https:// doi.org/10.1890/100008.

90. Lubin EA, Henry JT, Fiebig A, Crosson S, Laub MT. Identification of the PhoB regulon and role of $\mathrm{PhoU}$ in the phosphate starvation response of Caulobacter crescentus. de Boer P, editor. J Bacteriol. 2016;198(1):187-200. https://doi.org/10.1128/JB.00658-15.

91. Santos-Beneit $F$. The Pho regulon: a huge regulatory network in bacteria. Front Microbiol. Frontiers. 2015;6:402. https://doi.org/10.3389/fmicb.2015.00402.

92. Daims H, Lebedeva EV, Pjevac P, Han P, Herbold C, Albertsen M, et al. Complete nitrification by Nitrospira bacteria. Nature. Nature Publishing Group. 2015;528:504-9.

93. Martens-Habbena W, Berube PM, Urakawa H, de la Torre JR, Stahl DA. Ammonia oxidation kinetics determine niche separation of nitrifying Archaea and Bacteria. Nature. Nature Publishing Group. 2009;461:976-9.

94. Bouskill NJ, Eveillard D, Chien D, Jayakumar A, Ward BB. Environmental factors determining ammonia-oxidizing organism distribution and diversity in marine environments. Environ Microbiol. 2012;14(3):714-29. https://doi. org/10.1111/j.1462-2920.2011.02623.x.

95. Mosier AC, Francis CA. Relative abundance and diversity of ammoniaoxidizing archaea and bacteria in the San Francisco Bay estuary. Environ Microbiol. 2008;10(11):3002-16. https://doi.org/10.1111/j.1462-2920.2008.01 764.x.

96. Paerl HW, Pinckney JL. A mini-review of microbial consortia: their roles in aquatic production and biogeochemical cycling. Microb Ecol. 1996;31(3): 225-47. https://doi.org/10.1007/BF00171569.

97. Hallett CS, Valesini FJ, Kilminster K, Wells NS, Eyre BD. A rapid protocol for assessing sediment condition in eutrophic estuaries. Environ Sci Process Impacts. 2019;21(6):1021-37. https://doi.org/10.1039/C9EM00141G.
98. Kuypers MMM, Marchant HK, Kartal B. The microbial nitrogen-cycling network. Nat Rev Microbiol. Nature Publishing Group. 2018;16(5):263-76. https://doi.org/10.1038/nrmicro.2018.9.

99. Mohan SB, Cole JA. Chapter 7 - the dissimilatory reduction of nitrate to ammonia by anaerobic bacteria. In: Bothe H, Ferguson SJ, Newton WE, editors. Biol Nitrogen Cycle. Amsterdam: Elsevier; 2007. p. 93-106. https:// doi.org/10.1016/B978-044452857-5.50008-4.

100. Kraft B, Tegetmeyer HE, Sharma R, Klotz MG, Ferdelman TG, Hettich RL, et al. The environmental controls that govern the end product of bacterial nitrate respiration. Science. 2014;345(6197):676-9. https://doi.org/10.1126/science.12 54070.

101. Tiedje JM, Sexstone AJ, Myrold DD, Robinson JA. Denitrification: ecological niches, competition and survival. Antonie Van Leeuwenhoek. 1983;48(6): 569-83. https://doi.org/10.1007/BF00399542.

102. Wang S, Pi Y, Song Y, Jiang Y, Zhou L, Liu W, et al. Hotspot of dissimilatory nitrate reduction to ammonium (DNRA) process in freshwater sediments of riparian zones. Water Res. 2020;173:115539. https://doi.org/10.1016/j.watres.2 020.115539

103. Plummer $P$, Tobias $C$, Cady D. Nitrogen reduction pathways in estuarine sediments: influences of organic carbon and sulfide. J Geophys Res Biogeosciences. John Wiley \& Sons, Ltd. 2015;120:1958-72.

104. Smith MW, Herfort L, Rivers AR, Simon HM. Genomic signatures for sedimentary microbial utilization of phytoplankton detritus in a fast-flowing estuary. Front Microbiol. 2019;10:2475. https://doi.org/10.3389/fmicb.2019. 02475.

105. Baker BJ, Lazar CS, Teske AP, Dick GJ. Genomic resolution of linkages in carbon, nitrogen, and sulfur cycling among widespread estuary sediment bacteria. Microbiome. 2015;3(1):14. https://doi.org/10.1186/s40168-015-00776.

106. Yurkov W, Beatty JT. Aerobic anoxygenic phototrophic bacteria. Microbiol Mol Biol Rev. 1998;62(3):695-724. https://doi.org/10.1128/MMBR.62.3.695724.1998.

107. Grimm F, Franz B, Dahl C. Thiosulfate and sulfur oxidation in purple sulfur bacteria. In: Dahl C, Friedrich CG, editors. Microb Sulfur Metab. Berlin, Heidelberg: Springer; 2008. p. 101-16. https://doi.org/10.1007/978-3-540-72 682-1_9.

108. Béjà O, Suzuki MT, Heidelberg JF, Nelson WC, Preston CM, Hamada T, et al. Unsuspected diversity among marine aerobic anoxygenic phototrophs. Nature. 2002;415(6872):630-3. https://doi.org/10.1038/415630a.

109. Kobližek M. Ecology of aerobic anoxygenic phototrophs in aquatic environments. FEMS Microbiol Rev. Oxford Academic. 2015;39(6):854-70. https://doi.org/10.1093/femsre/fuv032.

110. Ghosh W, Dam B. Biochemistry and molecular biology of lithotrophic sulfur oxidation by taxonomically and ecologically diverse bacteria and archaea. FEMS Microbiol Rev. 2009;33(6):999-1043. https://doi.org/10.1111/j.1574-6976.2009.00187x.

111. Sessitsch A, Weilharter A, Gerzabek MH, Kirchmann H, Kandeler E. Microbial population structures in soil particle size fractions of a long-term fertilizer field experiment. Appl Environ Microbiol. 2001;67(9):4215-24. https://doi. org/10.1128/AEM.67.9.4215-4224.2001.

112. Rice EW, Bridgewater L, Association APH, Association AWW, Federation WE. Standard methods for the examination of water and wastewater. Washington D.C.: American Public Health Association; 2012.

113. Hugerth LW, Wefer HA, Lundin S, Jakobsson HE, Lindberg M, Rodin S, et al. DegePrime, a program for degenerate primer design for broad-taxonomicrange PCR in microbial ecology studies. Appl Environ Microbiol. 2014;80(16): 5116-23. https://doi.org/10.1128/AEM.01403-14.

114. Walters W, Hyde ER, Berg-Lyons D, Ackermann G, Humphrey G, Parada A, et al. Improved bacterial $16 \mathrm{~S}$ rRNA gene (V4 and V4-5) and fungal internal transcribed spacer marker gene primers for microbial community surveys. mSystems. 2016;1:e00009-15.

115. Kopylova E, Noé L, Touzet H. SortMeRNA: fast and accurate filtering of ribosomal RNAs in metatranscriptomic data. Bioinformatics. Oxford Academic. 2012;28(24):3211-7. https://doi.org/10.1093/bioinformatics/bts611.

116. Bushnell B. BBMap: a fast, accurate, splice-aware aligner. 2014; Available from: https://sourceforge.net/projects/bbmap/

117. Andrews S. FastQC: a quality control tool for high throughput sequence data. 2010; Available from: http://www.bioinformatics.babraham.ac.uk/ projects/fastqc/

118. Bolger AM, Lohse M, Usadel B. Trimmomatic: a flexible trimmer for Illumina sequence data. Bioinformatics. Oxford Academic. 2014;30(15):2114-20. https://doi.org/10.1093/bioinformatics/btu170. 
119. Miller CS, Baker BJ, Thomas BC, Singer SW, Banfield JF. EMIRGE: reconstruction of full-length ribosomal genes from microbial community short read sequencing data. Genome Biol. 2011;12(5):R44. https://doi.org/1 0.1186/gb-2011-12-5-r44.

120. Edgar RC. Search and clustering orders of magnitude faster than BLAST. Bioinformatics. 2010;26(19):2460-1. https://doi.org/10.1093/bioinformatics/ btq461.

121. Nurk S, Meleshko D, Korobeynikov A, Pevzner PA. metaSPAdes: a new versatile metagenomic assembler. Genome Res. 2017;27(5):824-34. https:// doi.org/10.1101/gr.213959.116.

122. Wood DE, Lu J, Langmead B. Improved metagenomic analysis with Kraken 2. Genome Biol. 2019;20(1):257. https://doi.org/10.1186/s13059-019-1891-0.

123. O'Leary NA, Wright MW, Brister JR, Ciufo S, Haddad D, McVeigh R, et al. Reference sequence (RefSeq) database at NCBI: current status, taxonomic expansion, and functional annotation. Nucleic Acids Res. 2016;44(D1):D73345. https://doi.org/10.1093/nar/gkv1189.

124. Lu J, Breitwieser FP, Thielen P, Salzberg SL. Bracken: estimating species abundance in metagenomics data. PeerJ Comput Sci. PeerJ Inc. 2017;3:e104.

125. Hyatt D, Chen G-L, LoCascio PF, Land ML, Larimer FW, Hauser LJ. Prodigal: prokaryotic gene recognition and translation initiation site identification. BMC Bioinformatics. 2010;11(1):119. https://doi.org/10.1186/1471-2105-11-11 9.

126. Haft DH, Selengut JD, White $O$. The TIGRFAMs database of protein families. Nucleic Acids Res. 2003;31(1):371-3. https://doi.org/10.1093/nar/gkg128.

127. Sonnhammer EL, Eddy SR, Birney E, Bateman A, Durbin R. Pfam: multiple sequence alignments and HMM-profiles of protein domains. Nucleic Acids Res. 1998;26(1):320-2. https://doi.org/10.1093/nar/26.1.320.

128. Eddy SR. Accelerated profile HMM searches. PLoS Comput Biol. 2011;7(10): e1002195. https://doi.org/10.1371/journal.pcbi.1002195.

129. Anantharaman K, Brown CT, Hug LA, Sharon I, Castelle CJ, Probst AJ, et al. Thousands of microbial genomes shed light on interconnected biogeochemical processes in an aquifer system. Nat Commun. Nature Publishing Group. 2016;7:13219.

130. Fish JA, Chai B, Wang Q, Sun Y, Brown CT, Tiedje JM, et al. FunGene: the functional gene pipeline and repository. Front Microbiol. Frontiers. 2013;4: 291.

131. Price MN, Dehal PS, Arkin AP. FastTree 2 - approximately maximumlikelihood trees for large alignments. PLoS One. Public Library of Science. 2010;5:e9490.

132. Sayers EW, Beck J, Brister JR, Bolton EE, Canese K, Comeau DC, et al. Database resources of the National Center for Biotechnology Information. Nucleic Acids Res. 2020;48(D1):9-16. https://doi.org/10.1093/nar/gkz899.

133. Buchfink $B$, Xie $C$, Huson DH. Fast and sensitive protein alignment using DIAMOND. Nat Methods. Nature Publishing Group. 2015;12(1):59-60. https:// doi.org/10.1038/nmeth.3176.

134. Liao Y, Smyth GK, Shi W. featureCounts: an efficient general purpose program for assigning sequence reads to genomic features. Bioinformatics. Oxford Academic. 2014;30:923-30. https://doi.org/10.1201/b16589.

135. Wagner GP, Kin K, Lynch VJ. Measurement of mRNA abundance using RNAseq data: RPKM measure is inconsistent among samples. Theory Biosci. 2012;131(4):281-5. https://doi.org/10.1007/s12064-012-0162-3.

136. Li B, Ruotti V, Stewart RM, Thomson JA, Dewey CN. RNA-Seq gene expression estimation with read mapping uncertainty. Bioinformatics. 2010; 26(4):493-500. https://doi.org/10.1093/bioinformatics/btp692.

137. R Core Team. R: a language and environment for statistical computing. 2018; Available from: https://www.R-project.org

138. Oksanen J, Blanchet FG, Friendly M, Kindt R, Legendre $P$, McGlinn D, et al. vegan: community ecology package. 2019; Available from: https://CRAN.Rproject.org/package=vegan

139. Martinez Arbizu P. pairwiseAdonis: pairwise multilevel comparison using adonis. 2019; Available from: https://github.com/pmartinezarbizu/pairwiseA donis

140. De'ath G, Therneau T. mvpart: multivariate partitioning. 2014; Available from: https://cran.microsoft.com/snapshot/2014-12-11/web/packages/mvpart/ index.html

141. Segata N, Boernigen D, Tickle TL, Morgan XC, Garrett WS, Huttenhower C. Computational meta'omics for microbial community studies. Mol Syst Biol. 2013;9(1):666. https://doi.org/10.1038/msb.2013.22.

142. Langfelder P, Horvath S. WGCNA: an R package for weighted correlation network analysis. BMC Bioinformatics. 2008;9(1):559. https://doi.org/10.11 86/1471-2105-9-559

\section{Publisher's Note}

Springer Nature remains neutral with regard to jurisdictional claims in published maps and institutional affiliations.
Ready to submit your research? Choose BMC and benefit from:

- fast, convenient online submission

- thorough peer review by experienced researchers in your field

- rapid publication on acceptance

- support for research data, including large and complex data types

- gold Open Access which fosters wider collaboration and increased citations

- maximum visibility for your research: over $100 \mathrm{M}$ website views per year

At BMC, research is always in progress.

Learn more biomedcentral.com/submissions 